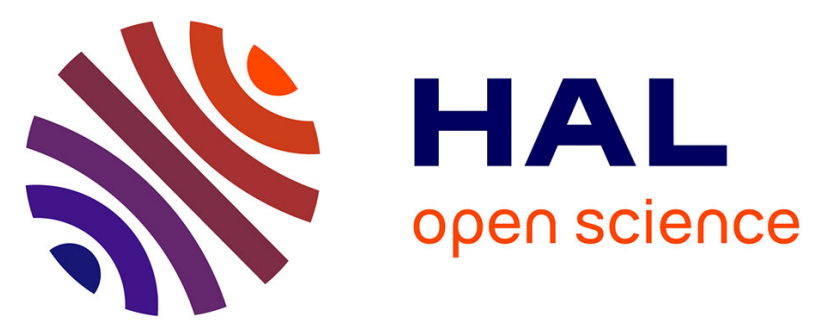

\title{
Permeability of sheeted dykes beneath oceanic ridges: Strain experiments coupled with 3D numerical modeling of the Troodos Ophiolite, Cyprus
}

Gabriel Coelho, Yannick Branquet, Stanislas Sizaret, Laurent Arbaret, Rémi Champallier, Olivier Rozenbaum

\section{To cite this version:}

Gabriel Coelho, Yannick Branquet, Stanislas Sizaret, Laurent Arbaret, Rémi Champallier, et al.. Permeability of sheeted dykes beneath oceanic ridges: Strain experiments coupled with 3D numerical modeling of the Troodos Ophiolite, Cyprus. Tectonophysics, 2015, 644-645, pp.138-150. 10.1016/j.tecto.2015.01.004 . insu-01110579

\section{HAL Id: insu-01110579 \\ https://hal-insu.archives-ouvertes.fr/insu-01110579}

Submitted on 28 Jan 2015

HAL is a multi-disciplinary open access archive for the deposit and dissemination of scientific research documents, whether they are published or not. The documents may come from teaching and research institutions in France or abroad, or from public or private research centers.
L'archive ouverte pluridisciplinaire HAL, est destinée au dépôt et à la diffusion de documents scientifiques de niveau recherche, publiés ou non, émanant des établissements d'enseignement et de recherche français ou étrangers, des laboratoires publics ou privés. 


\section{Accepted Manuscript}

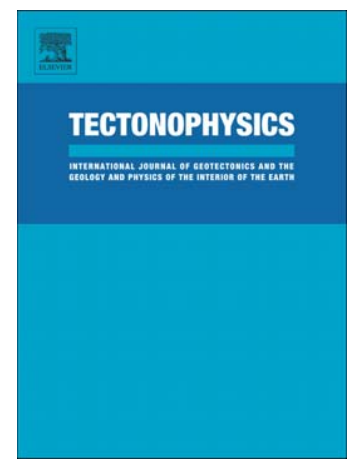

Permeability of sheeted dykes beneath oceanic ridges: Strain experiments coupled with 3D numerical modeling of the Troodos Ophiolite, Cyprus

Gabriel Coelho, Yannick Branquet, Stanislas Sizaret, Laurent Arbaret, Rémi Champallier, Olivier Rozenbaum

PII:

S0040-1951(15)00037-2

DOI:

doi: $10.1016 /$ j.tecto.2015.01.004

Reference: $\quad$ TECTO 126519

To appear in: $\quad$ Tectonophysics

Received date: 28 May 2014

Revised date: $\quad 8$ January 2015

Accepted date: 10 January 2015

Please cite this article as: Coelho, Gabriel, Branquet, Yannick, Sizaret, Stanislas, Arbaret, Laurent, Champallier, Rémi, Rozenbaum, Olivier, Permeability of sheeted dykes beneath oceanic ridges: Strain experiments coupled with 3D numerical modeling of the Troodos Ophiolite, Cyprus, Tectonophysics (2015), doi: 10.1016/j.tecto.2015.01.004

This is a PDF file of an unedited manuscript that has been accepted for publication. As a service to our customers we are providing this early version of the manuscript. The manuscript will undergo copyediting, typesetting, and review of the resulting proof before it is published in its final form. Please note that during the production process errors may be discovered which could affect the content, and all legal disclaimers that apply to the journal pertain. 
Permeability of sheeted dykes beneath oceanic ridges: Strain experiments coupled with 3D numerical modeling of the Troodos Ophiolite, Cyprus.

Gabriel Coelho ${ }^{1,2,3^{*}}$, Yannick Branquet ${ }^{1,2,3,4}$, Stanislas Sizaret ${ }^{1,2,3}$, Laurent Arbaret $^{1,2,3}$, Rémi Champallier ${ }^{1,2,3}$, Olivier Rozenbaum ${ }^{1,2,3}$

Affiliation :

${ }^{1}$ Univ d'Orléans, ISTO, UMR 7327, 45071, Orléans, France.

${ }^{2} \mathrm{CNRS} / \mathrm{INSU}$, ISTO, UMR 7327, 45071 Orléans, France.

${ }^{3}$ BRGM, ISTO, UMR 7327, BP 36009, 45060 Orléans, France.

${ }^{4}$ Géoscicences Rennes, UMR CNRS 6118, Université de Rennes 1, 35042 Rennes cedex, France.

*Correspondance to :

gabriel.coelho@univ-orleans.fr

Institut des Sciences de la Terre d'Orléans

UMR 7327 - CNRS/Université d'Orléans 
1A, Rue de la Férollerie

45071 OrléansCedex 2

France

$\mathrm{T}:+33(0) 238255381$

F: +33(0)238636488

\section{Introduction}

In a classical layer-cake oceanic crust, infiltration metasomatism is responsible for a strong and pervasive alteration of the basaltic rocks. Two hydrodynamics regimes for hydrothermal fluids and associated alteration are generally distinguished within the oceanic crust (see the review on oceanic metasomatism by Bach et al., 2013). The regime concerns ubiquitous circulation and associated pervasive alteration, which cause subtle changes in the major element composition. With the exception of the upper crust, the fluid flux is moderate and fluid-to-rock ratio close to 1 . The second regime involves localized and high fluid-flux upflow zones and subsequent venting in the vicinity of an axial ridge (Fig. 1; Alt, 1995). In this case, the mass transfers are particularly drastic within the sheeted dyke complex, leading to strong and widespread chloritization and epidotization (Fig. 1).

Epidosites are strongly Ca-metasomatized and metal-depleted rocks composed of an epidote-quartz assemblage in subequal proportions with the original igneous texture being completely overprinted (Richardson et al., 1987; Bach et al., 2013). Field and petrological data suggest that epidosites would correspond to the base (and likely, in part, to the source) of the ore-forming hydrothermal systems responsible for Cyprus-type volcanogenic massive sulfide deposition (e.g. Richardson et al., 1987). Epidosites are common and extensively studied in ophiolites as the Troodos complex, Cyprus (Richardson et al., 1987; Schiffman and 
Smith, 1988; Kelley and Robinson, 1990; Bickle and Teagle, 1992; Alt, 1994; Booij et al., 2000) and Oman (e.g. Nehlig, 1994). These rocks have also been observed in tectonically exposed mid- to lower arc crust (e.g. Banerjee et al., 2000). Conversely, they are not documented in current oceanic crust as epidosites are related to supra-subduction context and not mid-ocean ridge (Bach et al., 2013).

As localized upflow zones within sheeted dykes are characterized by strong metasomatism and associated very high fluid flux, permeability appears to be a major controlling factor in oceanic hydrothermalism. Large-scale permeability is assumed to favor large convection cells responsible for localizing upflow zones at vents (Fig. 1). One important clue common in most active/reactive natural geosystems, is that permeability of oceanic hydrothermal systems is typically transient, even on short time scales: (i) the tectonic and magmatic activity of oceanic ridges yields significant brittle strain which may enhance permeability through faults, fractures, and microcracks; (ii) metasomatism, and, more generally, fluid/rock interactions greatly influence porosity and resulting permeability temporally, either by opening spaces (e.g. dissolution or anisovolumetric replacement) or sealing cracks by hydrothermal phase deposition. Thus, assessing permeability in such systems requires accounting for fracture emplacement, hydrothermal sealing, and alteration degree of the diabase, which constitutes the sheeted dykes.

Permeability in oceanic crust is usually measured using three main approaches:

(i) in situ bulk permeability of extrusive volcanic rocks and sheeted dykes has been measured by the Deep Sea Drilling Project/Ocean Drilling Program (DSDP/ODP). Different techniques, like drill-string packer and thermal flow meter measurements (Becker, 1989; Fisher, 1998; Becker and Fisher, 2000), have been used. These direct measurements indicate a wide range of permeability values (Fig. 1). A well-established result is that permeability 
decreases with depth from $10^{-13} \mathrm{~m}^{2}$ in the upper few hundred meters of the seafloor to $10^{-18} \mathrm{~m}^{2}$ at 1200 meters depth (Fig. 1; Becker and Fisher, 2000);

(ii) inferred permeability using indirect approachs employ fracture and vein mapping of ophiolites (e.g. Cyprus, Oman). In these cases, permeability values are calculated using different methods including the parallel plate method, the matrix addition method, and the stochastic method (in the Troodos Ophiolite on Cyprus by Van Everdingen, 1995; in the Semail Ophiolite in Oman by Nehlig, 1994). In Oman, calculated permeability values vary between $10^{-11}$ and $10^{-12} \mathrm{~m}^{2}$ at the base of the sheeted dykes (Fig.1; Nehlig, 1994). In the Troodos Ophiolite, sheeted dykes have an on-axis permeability estimated between $10^{-12}$ and $10^{-8} \mathrm{~m}^{2}$ (Fig. 1), while fractured diabase containing calcite-filled veins have an off-axis permeability of $10^{-21}$ to $10^{-18} \mathrm{~m}^{2}$ (Van Everdingen, 1995). It is noteworthy that those inferred permeability values are dubious because they are calculated from outcrop data on the massive ophiolite scale, i.e. after weathering and stress relaxation induced by tectonic exhumation.

(iii) laboratory permeability measurements of oceanic rocks are seldom performed in the pressure/temperature conditions prevailing in oceanic crust hydrothermal systems (e.g. Aksyuk et al., 1992).

This large permeability variation range is partly explained by different the investigation depths, locations, and lithologies, however, the prevailing factor is the scale dependency of permeability measurements. This has been clearly established for the continental crust (Brace, 1980; Clauser, 1991; Townend and Zoback; 2000) and is unequivocally valid for the oceanic crust (see e.g. range of variations in Van Everdingen, 1995). In fact, laboratory measurements on centimeter-scale samples are systematically 3-4 orders of magnitude lower than large-scale measurements using in-situ or fracture mapping methods (Brace, 1980; Townend and Zoback; 2000). Moreover, small-scale laboratory permeability measurements obtained under estimated pressure and temperature conditions are not directly exploited when reconstructing or 
modeling hydrodynamics of Darcian hydrothermal systems. Thus, numerical hydro-thermal Darcian models of oceanic ridge convection cells currently use high large-scale permeability values mainly from ODP boreholes (e.g. $10^{-15}$ to $10^{-13} \mathrm{~m}^{2}$, Coumou et al., 2006; Fontaine and Wilcock, 2007).

Laboratory measurements make it possible to estimate and quantify the micro-mechanisms (e.g. structural, textural, and mineralogical) at play that directly control the intrinsic permeability at the centimeter scale. Laboratory data are therefore essential when studying transient physical conditions of oceanic hydrothermalism subjected to fracture emplacement and hydrothermal alteration. Experimental permeability measurements of rocks under estimated in situ confining and pore pressures, temperatures, and strains are technically challenging and have not yet been performed on oceanic materials. Such experiments, which evaluate the effects of deformation on permeability, have been mostly performed on granitic rocks (Zoback and Byerlee, 1975; David et al., 1999; Tenthorey and Gerald, 2006), sandstones (Tenthorey et al., 1998, 2003; Tenthorey and Cox, 2006), mudstones and fault gouge (e.g. Zhang and Cox, 2000), calcite (e.g. Zhang et al., 1994a) and serpentinites (Tenthorey and Cox, 2003; Hirose et al., 2006). Only one series of experiments (e.g. Tenthorey and Gerald, 2006) used water as pore fluid rather than argon. As water is a potentially reactive fluid, its use allows us to study the feedback between permeability and hydrothermal reactions, which may encourage the sealing of cracks and deformation.

This study reports permeability measurements conducted at temperatures, confining and fluid pressures common at the base of the sheeted dyke complex close to the reaction zone. We performed experiments with the three main rock types (metadiabase, chloritized metadiabase and epidosite) encountered in the sheeted dykes at Troodos Ophiolite complex (Cyprus). Moreover, applying differential stresses, we accounted for brittle deformation of rocks that occurs during oceanic crust spreading. Argon and water were used as the pore fluid 
in order to evaluate potential hydrothermal reactions (e.g. sealing of cracks) during our experiments. Finally, in order to explore effects of unloading and stress relaxation during ophiolite exhumation, we performed 3D void-space mapping numerical simulations to measure the core sample permeability after the laboratory experiments.

\section{Experimental constant conditions}

We used the well-defined stratigraphy of Troodos around Mt. Olympus (ICRDG drillholes CY1, 1a and 4; Vine and Smith, 1990) to choose our experimental conditions. The stratigraphic data indicates a thickness of rocks of about $2 \mathrm{~km}$ above the reaction zone (Fig. 1). A mean seawater depth above mid-ocean ridges of $3 \mathrm{~km}$ has been assumed. The lithostatic pressure at the base of the sheeted dyke complex is then close to $90 \mathrm{MPa}$. Since the thickness of volcanic and sedimentary rocks varies along axis for slow-spreading ridges (e.g. Cannat et al., 1995), the experimental confining pressure was fixed at $100 \mathrm{MPa}$. This configuration corresponds to a hydrostatic fluid pressure around $50 \mathrm{MPa}$ (Fig. 1). To a first order approximation, as in most numerical models (e.g. Fontaine and Wilcock, 2007), we assume a hydrostatic fluid pressure gradient. Therefore, a target pore fluid pressure at $50 \mathrm{MPa}$ was chosen.

The experimental temperature was chosen using data from fluid inclusion studies. At Troodos, trapping temperatures range between 300 and $400^{\circ} \mathrm{C}$ (Richardson et al., 1987; Schiffman and Smith, 1988; Kelley and Robinson, 1990; Kelley et al., 1992; Bettison-Varga et al., 1995). Similar temperatures have been estimated at the roofs of the magma chambers in other ophiolite complexes (e.g. Oman; Nehlig, 1991; Nehlig et al., 1994). Considering all these studies, the experimental temperature was held fixed at $400^{\circ} \mathrm{C}$. 


\section{Starting material}

We selected three representative lithologies of the Troodos sheeted dyke complex:

1) A diabase metamorphosed under greenschist facies conditions (close to the village of Askas; $\mathrm{X}=506547.522 ; \mathrm{Y}=3866086.848$; Cyprus metric grid). This sample is hereafter referred to as metadiabase. The selected sample is composed of quartz, calcic plagioclase (An64), actinolite, accessory chlorite and sparse magnetite (Fig. 2A). Microgranular doleritic texture is defined by spherulites of plagioclase and actinolite. Magnetite grains present ilmenite exsolutions. Therefore, most of the magmatic texture is preserved. Actinolite and chlorite are common to typical ocean-floor metamorphism, widespread in current oceanic floors (Honnorez, 2003). Their presence is considered to result from distal alteration processes away from the focused discharge area.

2) A strongly chloritized metadiabase with little evidence of epidotization (close to the village of Galata; $X=490689.092 ; Y=3875265.152)$. The selected sample is enriched in chlorite, the other phases being quartz, albite, actinolite, very small amount of epidote and sparse magnetite (Fig. 2B). The primary magmatic texture is less recognizable because of the intense chloritization. The degree of alteration of this sample is more intense than in the metadiabase.

3) An epidosite (from the Spilia-Kannavia epidosite zone; $X=496904.572$; $\mathrm{Y}=3869827.252$ ). The selected sample is composed of epidote, lobate quartz, chlorite, and titanite replacing ilmenite (Fig. 2C). The texture is granoblastic. This rock underwent pervasive alteration with intense chemical replacement, from processes in focused discharges of hydrothermal fluids proximal to the ridge axis (Honnorez, 2003).

All specimens were cored (30 $\mathrm{mm}$ in length and $10 \mathrm{~mm}$ in diameter) from large rock samples and dried at $45^{\circ} \mathrm{C}$ for three days for not adding water to the pore fluid system. 


\section{Experimental method and laboratory permeability measurements}

All measurements were conducted in an internal heated Paterson gas apparatus able to independently control confining pressure $(\mathrm{Pc})$, pore pressure $(\mathrm{Pp})$, temperature $(\mathrm{T})$, and longitudinal strain $(\varepsilon)$ (see details in Paterson, 1970). Pore fluid pressure is isolated from the argon confining medium by an iron jacket (Fig. 3) (Tenthorey and Cox, 2006). For each starting material (Table 1), two experiments were performed with either argon or de-ionized water as pore fluid to evaluate effects of potential hydrothermal phase deposition on permeability. In all experiments, the experimental procedure started by raising Pc up to the target level of $100 \mathrm{MPa}$. Then, pore pressure was progressively increased up to a value of 50 MPa. All specimens were initially heated to $500{ }^{\circ} \mathrm{C}$ for a period of 15 minutes to ensure coupling between the specimen and jacket (the jacket molds the sample at high temperature) and prevent fluid flow outside the specimen. Just after, we lowered the temperature to 400 from $500^{\circ} \mathrm{C}$ and permeability was measured before, during (at different stagnant steps of differential stress) and after deformation of the specimen (e.g. Fig. 4B). At each loading step, the strain rate was constant at $8 \times 10^{-5} \mathrm{~s}^{-1}$. Permeability was measured using the steady state flow method for Darcian flow, which consists of imposing a known pore pressure difference across the specimen $(\Delta \mathrm{P}$ in $\mathrm{Pa})$ and measuring the resultant flow rate $(\mathrm{Q})$, which is proportional to permeability $\left(\mathrm{k}\right.$ in $\mathrm{m}^{2}$ ). Since the fluid flux at both ends of the specimen is monitored before and after a pore pressure difference is imposed, the permeability can be calculated using the following equation:

$$
k=(\mu \times L \times Q) /(A \times \Delta P)
$$


where $\mu$ is fluid viscosity $\left(\mu=67.990 \times 10^{-6}\right.$ Pa.s for water and $\mu=49.057 \times 10^{-6}$ Pa.s for argon at $400^{\circ} \mathrm{C}$ and $50 \mathrm{MPa}$; Kestin et al., 1984; Younglove and Hanley, 1986), L (in m) is specimen length and $\mathrm{A}\left(\right.$ in $\left.\mathrm{m}^{2}\right)$ is specimen cross-sectional area.

The pore fluid system includes an upstream reservoir, the specimen column, and a downstream reservoir interconnected together by the pore fluid conduit, as described by Zhang et al. (1994b). Typical imposed pore pressure differences across the specimens during permeability measurements were $3 \mathrm{MPa}$. For this, the upstream pressure is automatically maintained at $50 \mathrm{MPa}$ using a servo-controlled volumometer. The volumometer consists of a cylinder (pore fluid reservoir) and a piston device, driven by a printed armature DC servomotor through reduction gears, and has a volume of $2000 \mathrm{~mm}^{3}$. The piston displacement, which keeps the upstream pressure constant, is measured with a DC-LVDT over time. The downstream pressure is maintained at $47 \mathrm{MPa}$ by the way of a micrometering needle valve. Thus, Q is calculated from the volume of fluid injected into the specimen (V) by the volumometer over time (see details in the appendix).

Error bars of laboratory permeability values were determined from the derivative of $\ln (\mathrm{k})$ :

$$
\frac{d k}{k}=\frac{d \mu}{\mu}+\frac{d L}{L}+\frac{\mathrm{dQ}}{\mathrm{Q}}-\frac{\mathrm{dA}}{\mathrm{A}}-\frac{d \Delta P}{\Delta P}
$$

The variations in $\mu, \mathrm{L}, \mathrm{A}$ and $\Delta \mathrm{P}$ during experiments are negligible relative to $\mathrm{Q}$. $\mathrm{Q}$, dependent of $\mathrm{V}$, may induce errors in $\mathrm{k}$ measurements for specimens presenting very low permeability $\left(\mathrm{k}<10^{-20} \mathrm{~m}^{2}\right)$ because a very small amount of fluid passes through those specimens. Thus, in this case only, the piston advances discontinuously: 


$$
\frac{d k}{k} \approx \frac{d Q}{Q} \text { and } d k=k \times \frac{d Q}{Q} \approx k \times \frac{d V}{V}
$$

Furnace calibrations indicate that there is, at most, a $5^{\circ} \mathrm{C}$ variation along the length of the specimen. At the end of each experiment, specimens were unloaded with no quenching. Confining and pore pressures were decreased in tandem. After all experiments, one third of the fractured specimen was cut to perform X-ray microtomography in order to obtain 3D images of the porous network and allow post-experiment permeability calculation. The other two-thirds of the specimen were used to make a polished thin section.

\section{Three-dimensional images of fracture networks and numerical permeability calculation after experiment}

After each experiment, 3D images of fracture networks were obtained and permeability was calculated through numerical simulations so as to compare these results with permeability measurements.

\subsection{Acquisition of $3 D$ images}

Microtomography analyses were performed using an industrial CT device (Nanotom 180NF; GE Phoenix|x-ray, Wunstorf, Germany) at the ISTO. This unit has an $180 \mathrm{kV}$ nanofocus X-ray tube and a digital detector array (2304X1152 pixels Hamamatsu detector). A target made of tungsten was used in order to obtain high accelerating voltage. Samples were placed in the chamber and rotated by 360 degrees during acquisition. The samples (in the form of $10 \mathrm{~mm}$ diameter rods) were mounted and waxed on a carbon fiber rod. An operating voltage of $160 \mathrm{kV}$ and a filament current of $23 \mu \mathrm{A}$ were applied. The distance between the X- 
ray source and the sample and between the X-ray source and the detector was 22 and $400 \mathrm{~mm}$, respectively, giving a voxel size of $5.5 \mu \mathrm{m}$. The 2000 projection images (angular increment of $0.18^{\circ}$ ) were acquired during rotation (with an acquisition time of 4 hours).

The resulting projections were converted into a 3D image stack using a microcluster of four PCs with the Phoenix 3D reconstruction software (filtered back projection Feldkamp algorithm; Feldkamp et al., 1984). The reconstruction software contains several different modules for artifact reduction (e.g. beam hardening, ring artefacts) to optimize the results. Theoretically, with a monochromatic X-ray (e.g., from a synchrotron beamline), the relation between pixel value (attenuation coefficient) and the compound's mass density is well defined by the Beer-Lambert equation (Peix et al., 2000). With a polychromatic X-ray beam, which is the case for laboratory XCT, artifacts are inevitable and difficult to remove. It is therefore difficult to lay pixel values with material densities in an absolute and quantitative manner. Frequently encountered artifacts include: beam hardening effect (Van de Casteele et al., 2004) where an object of uniform density appears to have a thick and dense skin or ring effect (Lumpkin et al., 2003), generally caused by temporary and spurious bad pixels in the detector. This effect can be reduced by the reconstruction software, but only to a certain extent and is less effective for a multi-component object. Using a filtered back projection algorithm, a computer reconstructed the projections to obtain cross-sectional images of the sample (tomograms). Stacking these reconstructed images forms a 3D image of the sample (volume dataset). At each space position of the resulting dataset, a grey-value corresponds to the effective X-ray attenuation coefficient. Therefore, if the principal compounds of the object are known and have a sufficient density contrast, the distribution of these compounds within the object can be easily deduced. Finally, the 16-bit 3D image was converted into 8-bit (256 grey levels) for the image analysis processing. 


\subsection{Segmentation and numerical calculation of permeability}

Calculation of permeability involves correctly segmenting the solid and the porous phases. Image segmentation, the process by which a greyscale image is converted into black and white voxels, was done using ImageJ (rsb.info.nih.gov/ij, accessed 01/2012). Because it was not possible to directly threshold the greyscale images we used two filters in order to obtain binary images (the fractures in black and the matrix in white). The first filter is " $\mathrm{A}$ Trous filter", which removes noise using wavelet-based analysis. After thresholding, the resulting binary (black and white) image was filtered with the "3D Analysis" plugin (Iannuccelli et al., 2010) so as to eliminate the smallest particles that correspond to noise. We visualized in 3D the fracture networks in the segmented volumes with the software Blob3D.

Single phase gas flow simulations were done through the segmented volumes using highly parallelized lattice Boltzmann code, Palabos (see details in Degruyter et al., 2010), running on a computer cluster at the ISTO. The segmented volumes were converted in an input file using a Matlab script where porous space is filled with a fluid and the walls of the porous medium are set to bounce-back boundary conditions. Palabos solves for the steadystate velocity field of the fluid flow caused by an imposed pressure gradient across two opposite ends of the segmented volume (the four other sides of the volume being sealed). Palabos was set so as to model a single phase, isothermal, laminar flow. Constant fluid viscosity and density were set to $1 / 6 \mathrm{~kg} / \mathrm{lu} / \mathrm{s}$ and $1 \mathrm{~kg} / \mathrm{lu}^{3}$, respectively. The symbol $\mathrm{lu}$ is the lattice unit length, which was set to the voxel edge length. The pressure gradient was on the order of $10^{-7} \mathrm{~kg} / \mathrm{lu}^{2} / \mathrm{s}^{2}$ so as to ensure laminar flow (i.e., Reynolds number $<<1$ ). Darcy's law is applied with the averaged stream-wise velocity component, the imposed pressure gradient, and the fluid viscosity to solve for permeability $k$ in nondimensional lattice units, $\mathrm{lu}^{2}$. This value is converted back to $\mathrm{m}^{2}$ by multiplying it by the square of the voxel edge length. For 
each volume, one permeability value is obtained in the vertical direction. The laminar and steady-state nature of the simulated flow was tested by ensuring that the permeability values were constants at different applied pressure gradients.

Fractures are narrow and sometimes only a few voxels across. It is to be expected that sample permeability is sensitive to thresholding. This was tested by successively eroding one voxel layer of the fracture and calculating the permeability at each erosion step. The permeability of a representative sample being of $3.4 \times 10^{-13} \mathrm{~m}^{2}$ initially, it decreased to $6.4 \times 10^{-}$ ${ }^{14} \mathrm{~m}^{2}, 1.2 \times 10^{-14} \mathrm{~m}^{2}$, and $3.7 \times 10^{-18} \mathrm{~m}^{2}$ for one, two, and eight successive erosions, respectively. We consider that our thresholding is accurate to \pm 1 voxels, which gives us a typical uncertainty of a factor 5 .

\section{Results}

\subsection{Laboratory permeability measurements}

\subsubsection{Permeability evolution of metadiabase}

For the first experiment on metadiabase (PP239, Table 1), argon was used as the pore fluid. Before deformation of the specimen, three permeability values were measured near $2.5 \times 10^{-20} \mathrm{~m}^{2}$ (Fig. 4A). Then, the specimen was subjected to axial loading until macroscopic failure appeared around $1000 \mathrm{MPa}$. Just after the failure and the unloading of the specimen, permeability increased by about one order of magnitude relative to the starting isostatic conditions. Despite the inert nature of argon, permeability tended to decrease with time to $4.2 \times 10^{-20} \mathrm{~m}^{2}$.

For the second experiment on metadiabase (PP274, Table 1), de-ionized water was used as pore fluid. Before deformation, two permeability values were measured near $4 \times 10^{-20}$ 
$\mathrm{m}^{2}$ (Fig. 4B). The specimen was then progressively loaded and permeability measured at each increment of differential stress. From the first increment (100 MPa) and until the macroscopic failure, permeability tended to decrease with time. Contrary to the experiment with Argon, the failure occurred at a lower differential stress of $700 \mathrm{MPa}$. Later on, a differential stress of 250 MPa was maintained with no permeability variation. A peak of permeability appears $\left(2.9 \times 10^{-}\right.$ $19 \mathrm{~m}^{2}$ ) after the complete unloading of the specimen. The end of the experiment is characterized by a slow regular decrease of permeability to a value around $6 \times 10^{-21} \mathrm{~m}^{2}$.

\subsubsection{Permeability evolution of strongly chloritized metadiabase}

In the experiment with argon (PP324, Table 1), no permeability was measured, even after the macroscopic failure (Fig. 5A). In fact, no Ar was injected into the sample, which appeared to be impermeable. Therefore, the specimen would have a permeability lower than $5 \times 10^{-21} \mathrm{~m}^{2}$, which corresponds to the minimum permeability measurable with the steady-state flow method (GSA repository item 2003132 of Tenthorey and Cox, 2003).

Using de-ionized water (PP298, Table 1), two permeability values were measured by infiltration of water before loading at different steps of differential stress. These initial values are between $1 \times 10^{-20}$ and $3 \times 10^{-20} \mathrm{~m} 2$ (Fig. 5B). For all loading steps, no measure of permeability was possible. The macroscopic failure occurred at a differential stress of 250 MPa. After that, a differential stress of $200 \mathrm{MPa}$ was maintained and permeability increased up to $2.6 \times 10^{-19} \mathrm{~m}^{2}$. Afterwards, permeability decreased with time to $2.5 \times 10^{-20} \mathrm{~m}^{2}$. Just after the unloading of the specimen, the permeability increased slightly to $3.4 \times 10^{-20} \mathrm{~m}^{2}$. Then, the sample had been re-shortened by $300 \mu \mathrm{m}$ by a slip along the macroscopic fracture which accommodated most of the displacement. Just after this second deformation, a complete unloading of the specimen was performed. At this moment, permeability increased to $1.0 \times 10^{-}$ 
${ }^{19} \mathrm{~m}^{2}$. Finally, permeability dropped quickly to $6.9 \times 10^{-21} \mathrm{~m}^{2}$, a value close to the minimum measureable permeability.

\subsubsection{Permeability evolution of epidosite}

With Argon as pore fluid (PP332, Table 1), two inital permeability values were approximately $1.1 \times 10^{-18} \mathrm{~m}^{2}$ (Fig. 6A). After the first two increments of differential stress (100 and $200 \mathrm{MPa}$ ), permeability decreased to $9.0 \times 10^{-19} \mathrm{~m}^{2}$. At the last increment of differential stress (300 MPa), permeability increased slightly to $1.0 \times 10^{-18} \mathrm{~m}^{2}$. Macroscopic failure occurred at a differential stress of $350 \mathrm{MPa}$. After that, a differential stress of $180 \mathrm{MPa}$ was maintained and permeability remained constant around $1.6 \times 10^{-18} \mathrm{~m}^{2}$. Permeability was not affected by the complete unloading of the specimen and no permeability reduction was observed. Permeability remained constant until the end of the experiment.

Using water as pore fluid (PP308, Table 1), two permeability values were measured close to $6.5 \times 10^{-19} \mathrm{~m}^{2}$ before deformation (Fig. 6B). After the first two steps of differential stress (100 and $200 \mathrm{MPa}$ ), permeability decreased to $4.3 \times 10^{-19} \mathrm{~m}^{2}$. At the last differential stress $(300 \mathrm{MPa})$, permeability increased slightly to $5.4 \times 10^{-19} \mathrm{~m}^{2}$. The macroscopic failure occurred at a differential stress of $350 \mathrm{MPa}$. After failure, a differential stress of $160 \mathrm{MPa}$ was maintained. Permeability decreased and stabilized at $2.1 \times 10^{-18} \mathrm{~m}^{2}$. After the complete unloading of the specimen, permeability increased to $2.5 \times 10^{-18} \mathrm{~m}^{2}$. Later on, permeability decreased slowly and stabilized at values close to $1.0 \times 10^{-18} \mathrm{~m}^{2}$.

\subsection{Analysis of microstructures and numerical calculations of permeability after experiments}

In this study, all analyses under scanning electron microscope (SEM) were conducted on polished thin sections using a TESCAN MIRA 3 XMU (voltage $=25 \mathrm{kV}$ ). 


\subsubsection{Fractured metadiabase}

In both experiments (PP239 and PP274), no gouge was observed under SEM along the main fractures. The main fractures were widely opened after experiments (Fig. 7A). Opened micro fractures perpendicular to $\sigma 1$ and a set of microcracks parallel to $\sigma 1$ are observable (Fig. 7B). In the argon experiment, an amorphous phase was observed within microcracks (Fig. 7C). Energy dispersive spectroscopy (EDS) analyses suggest that it possibly corresponds to silica. Both experiments present abundant crack textures suggestive of self-healing within quartz grains (Fig. 7D).

The 3D fracture networks reconstructed from micro-tomographic imaging are composed of conjugate shear fractures associated with thin fractures sub normal to $\sigma 1$ (Fig. 8A\&B). Close observations on sectional images showed that the fractures sub normal to $\sigma 1$ tends to follow curved mineral grain borders. Single phase gas flow simulations yield permeability values of $3.1 \times 10^{-13} \mathrm{~m}^{2}$ and $3.4 \times 10^{-13} \mathrm{~m}^{2}$ for the samples from experiments with argon (PP239) and water (PP274) respectively.

\subsubsection{Fractured strongly chloritized metadiabase}

After each experiment (PP324 and PP298), specimens were reddish colored. After the argon experiment (PP324), large quantities of water were present at the top and bottom of the sample column. Optical microscopic observations reveal that chlorite is completely redbrown, especially in experiments with argon used as pore fluid. Additionally, gouge along the main fractures is observed via SEM (Fig. 9A). The gouge contains intensely sheared minerals, in particular magnetite grains. Gouge is particularly developed where chlorite is the more abundant phase. Moreover, all of the fractures are thinner than those of metadiabase 
experiments. As for the experiments on metadiabase, in both experiments (argon and water as pore fluid) some quartz grains present crack textures suggestive of self-healing (Fig. 9B).

The 3D visualizations of the fracture networks of the two specimens (PP324 and PP298) present 3D discontinuities along the fractures (Fig. 8C\&D). These discontinuities precisely match with the gouge zones. On top of that, fracture networks are simple: no conjugate fractures and no fractures normal to $\sigma 1$ have been observed, contrary to the metadiabase experiments (Fig. 7). Single-phase gas flow simulations yield permeability values of about $1.6 \times 10^{-14} \mathrm{~m}^{2}$ and $5.1 \times 10^{-15} \mathrm{~m}^{2}$ for the samples from experiments with argon (PP324) and water (PP298) respectively. These values are lower than those for the metadiabase.

\subsubsection{Fractured epidosite}

SEM images reveal complex networks of porosity in the two specimens (PP332 and PP308). Conjugate fractures (Fig. 10A) and thin discontinuous fractures through chloritized zones are observed (Fig. 10B), in addition to an obvious initially large porosity (Fig. 10A). A specific microstructure was observed in the deformed epidosite: micro fractures localized and propagated along epidote grains boundaries (Fig. 10C). As for the fractured chloritized metadiabase, textures suggestive of self-healing in quartz grains were observed only in the experiment using water as the pore fluid (PP308) (Fig. 10D).

Because of the high initial porosity of the epidosite, from microtomographic images, it was not possible to isolate the fracture network developed during deformation in the epidosite. A single-phase gas flow simulation done through the initial porosity of epidosite before experiment yielded a permeability at $1.3 \times 10^{-19} \mathrm{~m}^{2}$. This calculated permeability approaches the starting permeability measured in our experiment using water as pore fluid (PP308). 


\section{Discussion}

\subsection{Effects of deformation and lithology on laboratory permeability measurements}

Our experiments show that each diabase alteration facies presents its own specific fracture pattern, independently of the pore fluid nature and the loading procedure used: i) the fractured metadiabase is characterized by conjugated shear macrofractures associated with micro-cracks sets parallel and sub-normal to $\sigma 1$; ii) the fractured chloritized metadiabase presents thin, discontinuous shear macrofractures filled with gouge where chlorite is abundant in the sample; and iii) the fractured epidosite presents conjugate shear fractures, which may be discontinuous where chlorite is abundant. These fractures are associated with cracks parallel to $\sigma 1$ and controlled by epidote and quartz grain interfaces. However, the geometry, the location, and the dips of macroscopic fractures may vary slightly for the same lithology. This is relevant to mechanical experimentation on natural samples in which structural and textural inheritance is not homogenous at the core sample scale.

During deformation of epidosite samples, initial loading steps trigger closure of preexisting cracks and lead to a small drop in permeability (Fig. 6). Before the macroscopic failure, permeability values increase as the result of vertical crack aperture. This compaction/dilatant evolution before failure is well known in studies dealing with granitic rocks (e.g. Zoback and Byerlee, 1975; Tenthorey and Gerald, 2006) and basaltic rocks (Fortin et al., 2011). This evolution is not observed in the experiments on metadiabase and chloritized metadiabase (Fig. 4B and 5B). The initial permeability drop is common to all lithologies and suggests closure of thermal cracks and micropores particularly abundant within the epidosite (see initial porosity on Fig. 10A). In contrast, absence of a dilatant stage for metadiabases suggests that these rocks accommodate part of the deformation by strain mechanism as 
pressure solution creep. In that sense, we interpret the fractures sub-normal to $\sigma 1$ as pressure solution joints, similar to "stylolites" and reopened after the experiment. This implies transport of silica which could be associated to rock failure processes, and re-precipitation in cracks by sealing and/or healing.

After macroscopic failure, the hydrodynamics are different depending on lithology. The macroscopic failure induces a classical peak of permeability for the chloritized metadiabase (Fig. 5B) and epidosite (Fig. 6). This is not observed for the metadiabase sample, the peak being achieved only at the complete unloading of the specimen (Fig. 4B). Therefore, we conclude that macroscopic shear fractures in metadiabase are not a major drain for fluids before unloading. Moreover, horizontal pressure solution joints (see above) might be responsible for limited vertical fluid flow.

The fact that unloading might be an important control for increasing permeability (Fig. 4B) is not described in similar experimental works (e.g. Tenthorey and Gerald, 2006). We suggest that shear fractures and associated damage zones oblique to $\sigma 1$ are subject to dilation when isostatic conditions are recovered. Those fractures then constitute major pathways for fluids.

\subsection{Hydrothermal reaction: healing, sealing and role of chlorite content}

There is permeability reduction after failure in all experiments with the exception of the experiments on chloritized metadiabase (PP324) and epidosite (PP332) with argon. We reproduce the same exponential decrease in permeability values observed in similar experiments (e.g. Zhang et al., 1994b; Tenthorey et al., 1998; Morrow et al., 2001; Tenthorey and Gerald, 2006). Under hydrothermal conditions, this evolution is interpreted to be the result of gradual chemical equilibration of the pore fluid with the host rock induced by fluid- 
rock reactions (Aharonov et al., 1998). Most of those studies assume that this equilibration is achieved by sealing of cracks associated with mineral precipitation. In our experiments cracked quartz grains display typical self-healing textures (Fig. 7D, 9B, 10D) with micro cavity alignments as described in experiments by Brantley et al. (1990) or in natural deformed rocks by Labaume and Moretti (2001). Moreover, the fast reaction kinetics involved in our experiments (from hours to days) are coherent with processes of healing rather than sealing (e.g. Brantley et al., 1990; Niemeijer and Spiers, 2006; Niemeijer et al., 2008; Gratier, 2011). Therefore, we conclude that a major controlling process of the time-dependent permeability reduction is healing of cracks driven by minimization of surface energy in the presence of aqueous fluids.

Nevertheless, we clearly identify an amorphous siliceous phase partially filling intergranular spaces and cracks (Fig. 7C). This kind of filling is not widespread in our experiments as it was only observed in one fractured sample (PP239). The origin of this silica is associated with fracture processes. The deposition of this amorphous phase in spaces is characteristic of a sealing process with fluid infiltration as defined by Ramsay (1980). The sealing of fractures by infiltration is considered to take between months and centuries (Renard et al., 2000; Gratier et al., 2003; Gratier, 2011). Thus, our experiment shows that sealing fractures with an amorphous siliceous phase is possible and faster at laboratory time scales, from hours to days. Such peculiar sealing textures (Fig. 7C) have not yet been recognized in similar experiments $\left(400^{\circ} \mathrm{C}\right.$, a confining pressure of $100 \mathrm{MPa}$ and a pore fluid pressure of 50 MPa) on natural rocks (Tenthorey and Gerald, 2006).

To summarize, our experiments clearly show that permeability reduction operates through processes of self-healing and sealing of fractures, in the presence of an aqueous fluid phase that ensure mass transport. 
This assumption is clearly verified with water as pore fluid for all lithologies, whereas experiments using argon as pore fluid need to be re-examined. Argon, an inert gas, was initially used to measure permeability independently of any hydrothermal reaction. However, three different permeability evolutions have been observed in the three tested diabase alteration facies. For epidosite (PP332), the permeability remained constant after macroscopic failure. This evolution was expected using an inert fluid medium, as it is observed in other studies (e.g. Tenthorey and Gerald, 2006). On the other hand: i) the experiment on the metadiabase (PP239) shows a return to the initial permeability values after the macroscopic failure; and ii) the experiment on the chloritized metadiabase (PP324), permeability never exceeded the measurement sensitivity. Closure mechanisms described above (self-healing and sealing) and the presence of water in the chloritized metadiabase sample column after the experiment, attest to the fact that water-rich fluids have been generated during experiments using argon as a pore fluid pressure. A potential source of water might be the dehydration of chlorite. Indeed, the red color of the chlorite after the experiment PP324 appears to be the result of oxidation. The mechanism of chlorite oxidation is well known to produce water (Borggaard et al., 1982) in oxidizing conditions close to our temperature and redox experimental conditions. In fact, using argon, we maximize hydrogen loss in the sample column, causing oxidation of the sample (Hamilton et al., 1964). Moreover, the formation of hematite, detected by X-Ray powder Diffraction (XRD, INEL diffractometer with a curved position-sensitive detector CPS120), corroborates the oxidizing conditions prevailing during experiments with argon (Fig. 11). Borggaard et al. (1982) demonstrated that chlorite oxidation, in addition to forming water, yields structural changes like an overall expansion of the c-dimension. As a result, from the beginning of the experiment, chlorite should have expanded and partly filled the initial low porosity. This hypothesis was verified by XRD after experiment (PP324): chlorite has a larger d(001) value than before the experiment (Fig. 11). 


\subsection{Scale and decompression effects on permeability}

Our starting laboratory permeability values of metadiabase are lower than drill-string packer measurements of in situ permeability $\left(10^{-18}\right.$ to $\left.10^{-17} \mathrm{~m}^{2}\right)$ in current sheeted dykes (Becker, 1989; Fisher, 1998; Becker and Fisher, 2000). As mentioned in the introduction, these differences of several orders of magnitude are explained by the scale dependency of permeability measurements (e.g. Brace, 1980; Townend and Zoback, 2000). Our natural samples have a diameter of $10 \mathrm{~mm}$ and have been intentionally selected from zones where very few microcracks occurred. In contrast, borehole permeability measurements deal with large volume in situ rocks, which are intensively fractured. However, fracture development in our experiments allows increasing permeability by at least one order of magnitude. Moreover, our initial values on metadiabases approach permeability values obtained in experimental studies on oceanic crustal basalt samples (Hamano, 1980; Johnson, 1980; Karato, 1983). Basalt permeability values vary significantly in those studies $\left(10^{-22}\right.$ to $\left.10^{-16} \mathrm{~m}^{2}\right)$ depending on the texture (fresh basalt vs. breccias basalt) and the diagenesis ( \pm smectite).

It is noteworthy that our single gas flow numerical simulations performed on samples after experiments vary between $10^{-13}$ and $10^{-15} \mathrm{~m}^{2}$ depending on tested lithologies $( \pm$ chlorite and epidote). Thus, after total decompression (i.e. the confining pressure is progressively decreased to 1 bar at the end of each experiment) and preparation of samples for X-Ray tomography, simulated permeability values are 4-6 orders of magnitude higher than experimental values determined under P-T conditions. This intuitive result is well explained by the effect of the confining pressure on permeability (e.g. Karato, 1983; David et al., 1999) which must be considered in permeability determinations contrary to some methods such as fracture mapping on ophiolitic outcrops (Nehlig, 1994; Van Everdingen, 1995). 


\section{Conclusion}

Our results clearly show the intrinsic relationship between deformation and hydrothermal reaction and its impacts on transient permeability in altered oceanic rocks from sheeted dyke complex at the centimeter scale. During the loading of the specimens, laboratory permeability values are lower than the initial values due to the compaction and the closure of the low porosity. Permeability increased slightly just before macroscopic failure only in the epidosite via a coalescence of microcracks that would be favored by many large quartz grains. Immediately following failure, permeability peaks and decreases in a few minutes using water as pore fluid. This closure of the porosity is explained by self-healing and/or sealing of microcracks. Contrary to the study of Tenthorey and Gerald (2006), our experiments using argon as the pore fluid on metadiabases show that permeability reduction is possible despite the inertia of this gas. Indeed, in chloritized samples, self-healing and/or sealing was possible using argon thanks to intrinsic water from oxidation of chlorite.

Fracture networks induced by deformation are influenced by mineralogy (chlorite content). After experiments in metadiabase, conjugate fractures, micro fractures perpendicular to $\sigma 1$ and numerous microcracks parallel to $\sigma 1$ in quartz grains were observed. With respect to the fractured strongly chloritized metadiabase, fracture emplacement was represented by few thin discontinuous fractures where chlorite is abundant (gouge zones).

After the laboratory experiments, the fractured samples were imaged and the permeability values modeled by numerical simulations were compared to the measured permeability values under P-T conditions. Our numerical simulations performed after experiments confirm that decompression greatly increases permeability by 4-6 orders of magnitude. Consequently, after high pressure experiments, textures studied by X-ray 
microtomography or microscopy have to be carefully interpreted in terms of size aperture and hydrodynamics in future experimental endeavors. Consequently, as already noticed by Brace (1980), inferred permeability measured from fracture spacing and apertures in outcrop are subject to severe overestimation.

Finally, the low, fracture-enhanced, centimeter-scale permeability values of different diabase alteration facies within the oceanic sheeted dyke complex are inadequate in explaining the very high fluid flux observed in localized upflow zone near and along oceanic ridges. At large scales, fluids are channelized through up to centimeter-scale connected fractures/faults network, resulting in higher large-scale permeability values, allowing free convection cells to develop. Although our short duration experiments are not designed to simulate oceanic metasomatism, micro-crack healing and sealing appear to be rapid phenomena, not favoring the physical percolation of metasomatic fluids.

\section{Acknowledgements}

We are very grateful to Eleni Gergiou-Morisseau (Geological Survey Department of Cyprus) for her warm welcome in Cyprus and her help in sampling. We would also like to thank Michel Pichavant and Luc Barbanson for supporting this project funded by FluxHyd, Calamine and the 3F INSU program. We counted on the expertise of Alain Burgisser on using Palabos. For the use of the computer clusters we thank Jean-Louis Rouet, Laurent Catherine and Emmanuel Le Trong (CCSC CaSciModOT).

\section{Appendix. Flow rate $Q$ measurement}


The volume of fluid injected into the specimen $(\mathrm{V})$ is monitored over time. Thus, $\mathrm{Q}$ is known by linear regression as shown in the figure $A\left(Q=0.0024 \mathrm{~mm}^{3} / \mathrm{s}\right)$. This figure represents the first Q measurement made on the metadiabase with water as pore fluid (PP274) before deformation. We can notice that the fluid is not continuously injected by the piston because of the initial low permeability of the sample $\left(4 \times 10^{-20} \mathrm{~m}^{2}\right)$. Whereas after failure and the complete unloading of the specimen, the fluid is continuously injected (Fig. B; Q $=0.025$ $\mathrm{mm}^{3} / \mathrm{s}$ and $\mathrm{k}=2.9 \times 10^{-19} \mathrm{~m}^{2}$ ).

\section{References}

rsb.info.nih.gov/ij (accessed 01/2012)

Aharonov, E., Tenthorey, E., Scholz, C.H., 1998. Precipitation sealing and diagenesis: 2. Theoretical analysis. J. Geophys. Res. 103, 23969-23981.

Aksyuk, A. M., Vitovtova, V.M., Pustovoy, A.A., Kharin, G.S., Shmonov, V.M., 1992. The permeability of oceanic basalts and some questions of the formation of hydrothermal springs in the rift zone of the Atlantic Ocean. Oceanology, Engl. Transl., 32, 778-784.

Alt, J., 1994. A sulfur isotopic profile through the Troodos ophiolite, Cyprus - Primary composition and the effects of seawater hydrothermal alteration. Geochim. Cosmochim. Acta 58, 1825-1840.

Alt, J., 1995. Subseafloor processes in mid-ocean ridge hydrothermal systems, in: Humphris, S.E., Zierenberg, R.A., Mullineaux, L.S., Thomson, R.E. (Eds.), Seafloor 
hydrothermal systems: Physical, chemical, biological, and geological interactions. AGU Monograph Series, No. 91. American Geophysical Union, Washington, DC, pp. 85-114.

Bach, W., Jöns, N., Klein, F., 2013. Metasomatism within the ocean crust, in: Harlov, D.E., Austrheim, H. (Eds.), Metasomatism and the chemical transformation of rock. The role of fluids in terrestrial and extraterrestrial processes. Springer, pp. 252-288.

Banerjee, N.R., Gillis, K.M., Muehlenbachs, K., 2000. Discovery of epidosites in a modern oceanic setting, the Tonga forearc. Geology 28, 151-154.

Becker, K., 1989. Measurements of the permeability of the sheeted dikes in hole 504B, ODP LEG 111. Proc. ODP, Sci. Results 111, 317-325.

Becker, K., Fisher, A.T., 2000. Permeability of upper oceanic basement on the eastern flank of the Juan de Fuca Ridge determined with drill-string packer experiments. J. Geophys. Res. 105, 897-912.

Bettison-Varga, L., Schiffman, P., Janecky, D.R., 1995. Fluid-rock interaction in the hydrothermal upflow zone of the Solea graben, Troodos Ophiolite, Cyprus. Geol. Soc. Am. Spec. Pap. 296, 81-100.

Bickle, M.J., Teagle, D.A.H., 1992. Strontium alteration in Troodos ophiolite: Implications for fluid fluxes and geochemical transport in mid-ocean ridge hydrothermal systems. Earth Planet. Sci. Lett. 113, 219-237. 
Booij, E., Bettison-Varga, L., Farthing, D., Staudigel, H., 2000. Pb-isotope systematics of a fossil hydrothermal system from the Troodos ophiolite, Cyprus: Evidence for a polyphased alteration history. Geochim. Cosmochim. Acta 64, 3559-3569.

Boorgaard, O.K., Lindgreen, H.B., Mørup, S., 1982. Oxidation and reduction of structural iron in chlorite at $480^{\circ} \mathrm{C}$. Clays Clay Miner. 30, 353-364.

Brace, W.F., 1980. Permeability of crystalline and argillaceous rocks. Int. J. Rock Mech. Min. Sci. \& Geomech. Abstr. 17, 241-251.

Brantley, S.L., Evans, B., Hickman, S.H., Crerar, D.A., 1990. Healing of microcracks in quartz: Implications for fluid flow. Geology 18, 136-139.

Cannat, M., Mével, C., Maia, M., Deplus, C., Durand, C., Gente, P., Agrinier, P., Belarouchi, A., Dubuisson, G., Humier, E., Reynolds, J., 1995. Thin crust, ultramafic exposures, and rugged faulting patterns at the Mid-Atlantic Ridge $\left(22^{\circ}-24^{\circ} \mathrm{N}\right)$. Geology 23 , 4952.

Clauser, C., 1991, Permeabilität kristalliner Gesteine: Hannover, Niedersächsisches Landesamt für Bodenforschung (NLfB), Report 107776, 23 p.

Coumou, D., Driesner, T., Geiger, S., Heinrich, C.A., Matthäi, S. 2006. The dynamics of midocean ridge hydrothermal systems: Splitting plumes and fluctuating vent temperatures. Earth Planet. Sci. Lett. 245, 218-231. 
David, C., Menéndez, B., Darot, M., 1999. Influence of stress-induced and thermal cracking on physical properties and microstructure of La Peyratte granite. Int. J. Rock Mech. Min. Sci. 36, 433-448.

Degruyter, W., Burgisser, A., Bachmann, O., Malaspinas, O., 2010. Synchrotron X-ray microtomography and lattice Boltzmann simulations of gas flow through volcanic pumices. Geosph. 6, 470-481.

Feldkamp, L.A., Davis, L.C., Kress, J.W., 1984. Box-skeletons of discrete solids. J. Opt. Soc. Am. A1, 612-619.

Fisher, A.T., 1998. Permeability within basaltic oceanic crust. Rev. Geophys. 36, 143-182.

Fontaine, F.J., Wilcock, W.S.D., 2007. Two-dimensional numerical models of open-top hydrothermal convection at high Rayleigh and Nusselt numbers: Implications for midocean ridge hydrothermal circulation. Geochem. Geophys. Geosyst. 8, doi: 10.1029/2007GC001601.

Fortin, J., Stanchits, S., Vinciguerra, S., Guéguen, Y., 2011. Influence of thermal and mechanical cracks on permeability and elastic wave velocities in a basalt from Mt. Etna volcano subjected to elevated pressure. Tectonophysics 503, 60-74. 
Gratier, J.P., Favreau, P., Renard, F., 2003. Modeling fluid transfer along Californian faults when integrating pressure solution crack sealing and compaction process. J. Geophys. Res. 108, 28-52.

Gratier, J.P., 2011. Fault permeability and strength evolution related to fracturing and healing episodic processes (years to millennia): The role of pressure solution. Oil \& Gas Science Technol. 66, 491-506.

Hamano, Y., 1980. Physical properties of basalts from Holes 417D and 418A. Initial Rep. Deep Sea Drill. Proj., 51, 52, 53, 1457-1466.

Hamilton, D.L., Burnham, C.W., Osborn, E.F., 1964. The solubility of water and effects of oxygen fugacity and water content on crystallization in mafic magmas. J. Petrol. 5, 2139.

Hirose, T., Bystricky, M., Kunze, K., Stünitz H., 2006. Semi-brittle flow during dehydration of lizardite-chrysotile serpentinite deformed in torsion. Earth Planet. Sci. Lett. 249, 484-493.

Honnorez, J., 2003. Hydrothermal alteration vs. ocean-floor metamorphism. A comparision between two case histories: The TAG hydrothermal mound (Mid-Atlantic Ridge) vs. DSDP/ODP Hole 504B (Equatorial East Pacific). C.R. Geoscience 335, 781-824. 
Iannuccelli, E., Mompart, F., Gellin, J., Lahbib-Mansais, Y., Yerle, M., Boudier, T., 2010. NEMO: A tool for analyzing gene and chromosome territory distributions from 3DFISH experiments. Bioinforma. 26, 696-697.

Johnson, D.M., 1980. Crack distribution in the upper oceanic crust and its effects upon seismic velocity, seismic structure, formation permeability, and fluid circulation. Initial Rep. Deep Sea Drill. Proj., 51, 52, 53, 1479-1490.

Karato, S., 1983. Physical properties of basalts from Deep Sea Drilling Project Hole 504B. Initial Rep. Deep Sea Drill. Proj., 69, 687-695.

Kelley, D.S., Robinson, P.T., 1990. Development of a brine-dominate hydrothermal system at temperatures of $400 \sim 500^{\circ} \mathrm{C}$ in the upper level plutonic sequence, Troodos ophiolite, Cyprus. Geochim. Cosmochim. Acta 54, 653-661.

Kelley, D.S., Robinson, P.T., Malpas, J.G., 1992. Processes of brine generation and circulation in the oceanic crust: Fluid inclusion evidence from the Troodos ophiolite, Cyprus. J. Geophys. Res. 97, 9307-9322.

Kestin, J., Sengers, J.V., Kamgar-Parsi, B., Levelt Sengers, J.M.H., 1984. Thermophysical properties of fluid H2O. J. Phys. Chem. 13, 175-183.

Labaume, P., Moretti, I., 2001. Diagenesis-dependence of cataclastic thrust fault zone sealing in sandstones. Example from the Bolivian Sub-Andean Zone. J. Struct. Geol. 23, 1659-1675. 
Lumpkin, A., Yang, B., Yao, C., Emery, L., 2003. X-ray imaging of the aps storage ring beam stability effects: From the alaskan earthquake to undulator field changes. Med. Imaging 4, 2423-2425.

Morrow, C.A., Moore, D.E., Lockner, D.A., 2001. Permeability reduction in granite under hydrothermal conditions. J. Geophys. Res. 106, 30551-30560.

Nehlig, P., 1991. Salinity of oceanic hydrothermal fluids: A fluid inclusion study. Earth Planet. Sci. Lett. 102, 310-325.

Nehlig, P., 1994. Fracture and permeability analysis in magma-hydrothermal transition zones in the Samail ophiolite (Oman). J. Geophys. Res. 99, 589-601.

Nehlig, P., Juteau, T., Bendel, V., Cotten, J., 1994. The root zones of oceanic hydrothermal systems: Constraints from the Samail ophiolite (Oman). J. Geophys. Res. 99, 47034713.

Niemeijer, A.R., Spiers, C.J., 2006. Velocity dependence of strength and healing behaviour in simulated phyllosilicate-bearing fault gouge. Tectonophysics 427, 231-253.

Niemeijer, A.R., Marone, C., Elsworth, D., 2008. Healing of simulated fault gouges aided by pressure solution: Results from rock analogue experiments. J. Geophys. Res. 113, B04204, doi: 101029/2007JB005376. 
Paterson, M.S., 1970. A high-pressure, high-temperature apparatus for rock deformation. Int. J. Rock Mech. Min. Sci. 7, 517-526.

Peix, G., Duvauchelle, P., Freud, N., 2000. General principles, in: Baruchel, J., Buffiere, J.Y., Maire, E., Merle, P., Peix, G. (Eds.), X-Ray tomography in material science. Hermes Science, Paris, pp. 15-27.

Ramsay, J.G., 1980. The crack-seal mechanism of rock deformation. Nature 284, 135-139.

Renard, F., Gratier, J.P., Jamveit, B., 2000. Kinetics of crack-sealing, intergranular pressure solution and compaction around active faults. J. Struct. Geol. 22, 1395-1407.

Richardson, C.J., Cann, J.R., Richards, H.G., Cowan, J.G., 1987. Metal-depleted root zones of the Troodos ore-forming hydrothermal systems, Cyprus. Earth Planet. Sci. Lett. 84, 243-253.

Schiffman, P., Smith, B.M., 1988. Petrology and oxygen isotope geochemistry of a fossil seawater hydrothermal system within the Solea Graben, Northern Troodos Ophiolite, Cyprus. J. Geophys. Res. 93, 4612-4624.

Tenthorey, E., Scholz, C.H., Aharonov, E., 1998. Precipitation sealing and diagenesis. 1. Experimental results. J. Geophys. Res. 103, 23951-23967. 
Tenthorey, E., Cox, S.F., Todd, H.F., 2003. Evolution of strength recovery and permeability during fluid-rock reaction in experimental fault zones. Earth Planet. Sci. Lett. 206, 161-172.

Tenthorey, E., Cox, S.F., 2003. Reaction-enhanced permeability during serpentinite dehydration. Geology 31, 921-924.

Tenthorey, E., Gerald, J.D., 2006. Feedbacks between deformation, hydrothermal reaction and permeability evolution in the crust: Experimental insights. Earth Planet. Sci. Lett. 247, 117-129.

Tenthorey, E., Cox, S.F., 2006. Cohesive strengthening of fault zones during the interseismic period: An experimental study. J. Geophys. Res. 111, doi: 10.1029/2005JB004122.

Townend, J., Zoback, M.D., 2000. How faulting keeps the crust strong. Geology 28, 399-402.

Van de Casteele, E., Van Dyck, D., Sijbers, J., Raman, E., 2004. The effect of beam hardening on resolution in x-ray microtomography. Med. Imaging 5370, 2089-2096.

Van Everdingen, D.A., 1995. Fracture characteristics of the sheeted dike complex, Troodos ophiolite, Cyprus: Implications for permeability of oceanic crust. J. Geophys. Res. 100, 19957-19972.

Vine, F.J., Smith, G.C., 1990. Structural and physical properties of the Troodos crustal section at ICRDG drillholes CY1, 1a and 4, in: Malpas, J., Moores, E.M., Panayiotou, A., 
Xenophontos, C. (Eds.), Ophiolites: Oceanic crustal analogues. Proceedings of the symposium "Troodos 1987". Ministry of Agriculture and Natural Resources Geological Survey Department, Republic of Cyprus, Nicosia, Cyprus, pp. 113-124.

Younglove, B.A., Hanley, H.J.M., 1986. The viscosity and thermal conductivity coefficients of gaseous and liquid argon. J. Phys. Chem. 15, 1323-1337.

Zhang, S., Cox, S.F., Paterson, M.S., 1994a. The influence of room temperature deformation on porosity and permeability in calcite aggregates. J. Geophys. Res. 99, 15761-15775.

Zhang, S., Paterson, M.S., Cox, S.F., 1994b. Porosity and permeability evolution during hot isostatic pressing of calcite aggregates. J. Geophys Res. 99, 15741-15760.

Zhang, S., Cox, S.F., 2000. Enhancement of fluid permeability during shear deformation of a synthetic mud. J. Struct. Geol., 22, 1385-1393.

Zoback, M.D., Byerlee, J.D., 1975. The effect of microcrack dilatancy on the permeability of Westerly granite. J. Geophys. Res. 80, 752-755.

\begin{abstract}
Permeability laboratory measurements under in-situ pressures, temperature and strain have been performed on three different diabase alteration facies (metadiabase, chloritized diabase, epidosite) from the Troodos Ophiolite, Cyprus. This aims to study the relations between hydrodynamics, deformation and hydrothermal reaction in the sheeted dyke complex beneath oceanic ridges. The use of water as pore fluid in these experiments favors hydrothermal fluid-rock interactions. All experiments, performed with a Paterson gas-medium
\end{abstract}


apparatus, were achieved at $400^{\circ} \mathrm{C}, 100 \mathrm{MPa}$ of confining pressure and $50 \mathrm{MPa}$ of pore fluid pressure, conditions at the base of sheeted dykes. Permeability was measured by injection of water and argon before, during and after coaxial deformation. Resulting textures and mineralogy were studied by microscopy and X-ray microtomography in order to identify mineral reactions and to calculate the permeability by numerical simulation after decompression.

During stress loading, a compaction/dilatant evolution is observed only in experiments on epidosite. Failure tends to increase permeability by one order of magnitude. For example, using water as pore fluid, permeability measurements after macroscopic failure give the following variations from $4 \times 10^{-20} \mathrm{~m}^{2}$ to $2.9 \times 10^{-19} \mathrm{~m}^{2}$ for metadiabase, $1 \times 10^{-20} \mathrm{~m}^{2}$ to $2.6 \times 10^{-19}$ $\mathrm{m}^{2}$ for chloritized diabase and $6.5 \times 10^{-19} \mathrm{~m}^{2}$ to $3 \times 10^{-18} \mathrm{~m}^{2}$ for epidosite.

Textures suggestive of self-healing and sealing explain permeability reduction by hydrothermal reaction after macroscopic failure. Paradoxically, even using argon as pore fluid, hydrothermal reaction is possible in metadiabases due to dehydration of chlorite. Moreover, fractures appear much finer in rocks enriched in chlorite because of formation of gouge structures. After experiments, 3D images of fracture networks enable to calculate permeability by numerical simulations which values are 4-6 orders of magnitude higher than the experimental measured values. Such results demonstrate that the geometry and the textures observed in unloaded samples are not suitable to estimate permeability and have to be very carefully interpreted.

Keywords: permeability; experiments; deformation; sheeted dykes; epidosite; numerical simulations. 
Fig. 1. Diagram of a typical hydrothermal system within an oceanic ridge axial zone (modified from Alt, 1995). Permeability data of the sheeted dyke complex are compiled from two different methods: fracture and vein mapping in ophiolites (Nehlig, 1994; van Everdingen, 1995) and in situ measurements in current oceanic crusts (Becker and Fisher, 2000). Notice that hydrothermal fluid flow (recharge area, reaction zone and discharge area) can be represented in two directions (perpendicular and parallel to ridge axis).

Fig. 2. Photomicrographs in crossed polars of the three lithologies sampled from sheeted dikes in Troodos ophiolite. (A) Metadiabase presenting relics of doleritic texture (spherulites of actinolite and plagioclase feldspar). The magmatic texture is well preserved despite the reequilibration in the greenschist facies conditions. (B) Strongly chloritized metadiabase, spherulites of plagioclase grains are less discernible. (C) Epidosite enriched in epidote and quartz. Magmatic texture is overprinted by an intense metasomatic replacement leading to a granoblastic texture. Abbreviations: Act = Actinolite; Chl = Chlorite; Ep = Epidote; Plag = Plagioclase; Qtz $=$ Quartz.

Fig. 3. Sketch of sample column assembly used in all experiments. Pore fluids are isolated from the argon confining medium by an iron jacket with toric joints at the top and bottom of column. Notice that a copper jacket is inserted between the specimen and the iron jacket in order: i) to minimize risk of jacket rupture during failure of the specimen; ii) to allow perfect coupling between the specimen and jacket, preventing any fluid shortcut of pore fluid flow.

Fig. 4. Permeability evolutions of metadiabase from the sheeted dyke complex of Troodos Ophiolite using argon (A) and water as pore fluids (B). In (A), permeability was measured before and after macroscopic failure. In (B), permeability was measured at different steps of differential stress. The minimum permeability measurable by the steady-state flow method is fixed at $5 \times 10^{-21} \mathrm{~m}^{2}$ (GSA repository item 2003132 of Tenthorey and Cox, 2003) and represented by blue dashes.

Fig. 5. Permeability evolutions of strongly chloritized metadiabase from the sheeted dyke complex of Troodos Ophiolite using argon (A) and water as pore fluids (B). In (A), it was not possible to measure the permeability before and after macroscopic failure. So, using argon as pore fluid, permeability was certainly lower than the 
minimum permeability measurable by the steady-state flow method represented by blue dashes $\left(5 \times 10^{-21} \mathrm{~m}^{2}\right.$; GSA repository item 2003132 of Tenthorey and Cox, 2003). In (B), it was not possible to measure the permeability during deformation before macroscopic failure. When permeability stabilized after macroscopic failure, the specimen was deformed again with a slip (Sl) of $300 \mu \mathrm{m}$ on the fracture.

Fig. 6. Permeability evolutions of epidosite from the sheeted dyke complex of Troodos Ophiolite using argon (A) and water as pore fluids (B). In (A\&B), permeability was measured at different steps of differential stress. Notice that the error bars of permeability measurements are almost zero.

Fig. 7. SEM micrographs showing microstructures and typical textures after experiments on metadiabase (in all images $\sigma 1$ is vertical). (A) SEM image of the top of the fractured specimen after experiment with water (PP274). Note that the lower part of the sample is missing because it has been cut for X-Ray microtomography. (B) SEM image showing microcracks parallel to $\sigma 1$ and a microfracture subnormal to $\sigma 1$ in the fractured specimen after experiment with argon (PP239). (C) High magnification SEM image of same specimen as in (B) showing an amorphous siliceous phase between quartz and plagioclase feldspar grains. (D) High magnification SEM image of same specimen as in (A) showing a grain of quartz presenting self-healing texture (S-H). Abbreviations for minerals: Act = Actinolite Mag = Magnetite Plag = Plagioclase $;$ Qtz = Quartz .

Fig. 8. 3D visualizations (using the software Blob3D) of the fracture network of one part of each specimen. $\sigma 1$ is parallel to $\mathrm{Z}$ axis. Microcracks could not be segmented because of the resolution (the voxel size is approximately $5.5 \mu \mathrm{m})$. Fracture networks of metadiabase from the experiments using argon (A) and water (B) as pore fluids. Fracture networks of strongly chloritized metadiabase from the experiments using argon (C) and water (D) as pore fluids.

Fig. 9. SEM micrographs showing microstructure and typical textures after experiments on strongly chloritized metadiabase (in all images $\sigma 1$ is vertical). (A) SEM image of a gouge in the water experiment (PP298). (B) High magnification SEM image of same specimen as in (A) showing a grain of quartz presenting self-healing texture (S-H). Abbreviations for minerals: Chl = Chlorite; Mag = Magnetite; Plag = Plagioclase; Qtz = Quartz. 
Fig. 10. SEM micrographs showing microstructure and typical textures after experiments on epidosite (in all images $\sigma 1$ is vertical; images from the water experiment PP308). (A) SEM image showing conjugate fractures and the initial porosity (I.P.). (B) SEM image showing a discontinuous thin fracture because of chlorite. (C) SEM image showing micro fractures along epidote grains. (D) High magnification SEM image showing a grain of quartz presenting self-healing texture $(\mathrm{S}-\mathrm{H})$. Abbreviations for minerals: $\mathrm{Chl}=$ Chlorite; Ep = Epidote; Qtz = Quartz.

Fig. 11. XRD records from the strongly chloritized metadiabase (SCM) before (grey line) and after (black line) experiment using argon as pore fluid (PP324).

Fig. A. V vs. time diagram for the first Q measurement before deformation (PP274).

Fig. B. V vs. time diagram for Q measurement after failure and complete unloading of the specimen (PP274). 


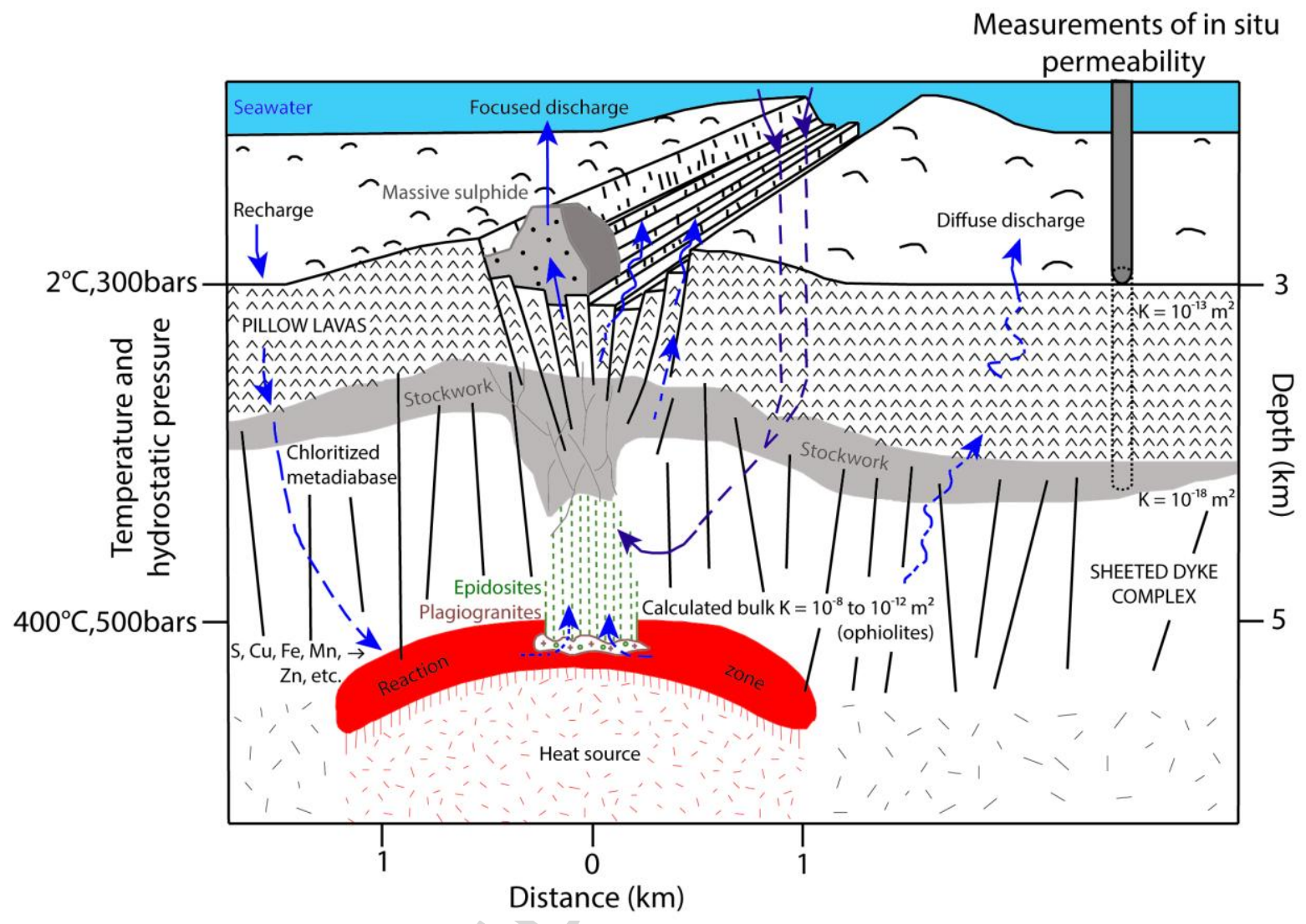

Figure 1 

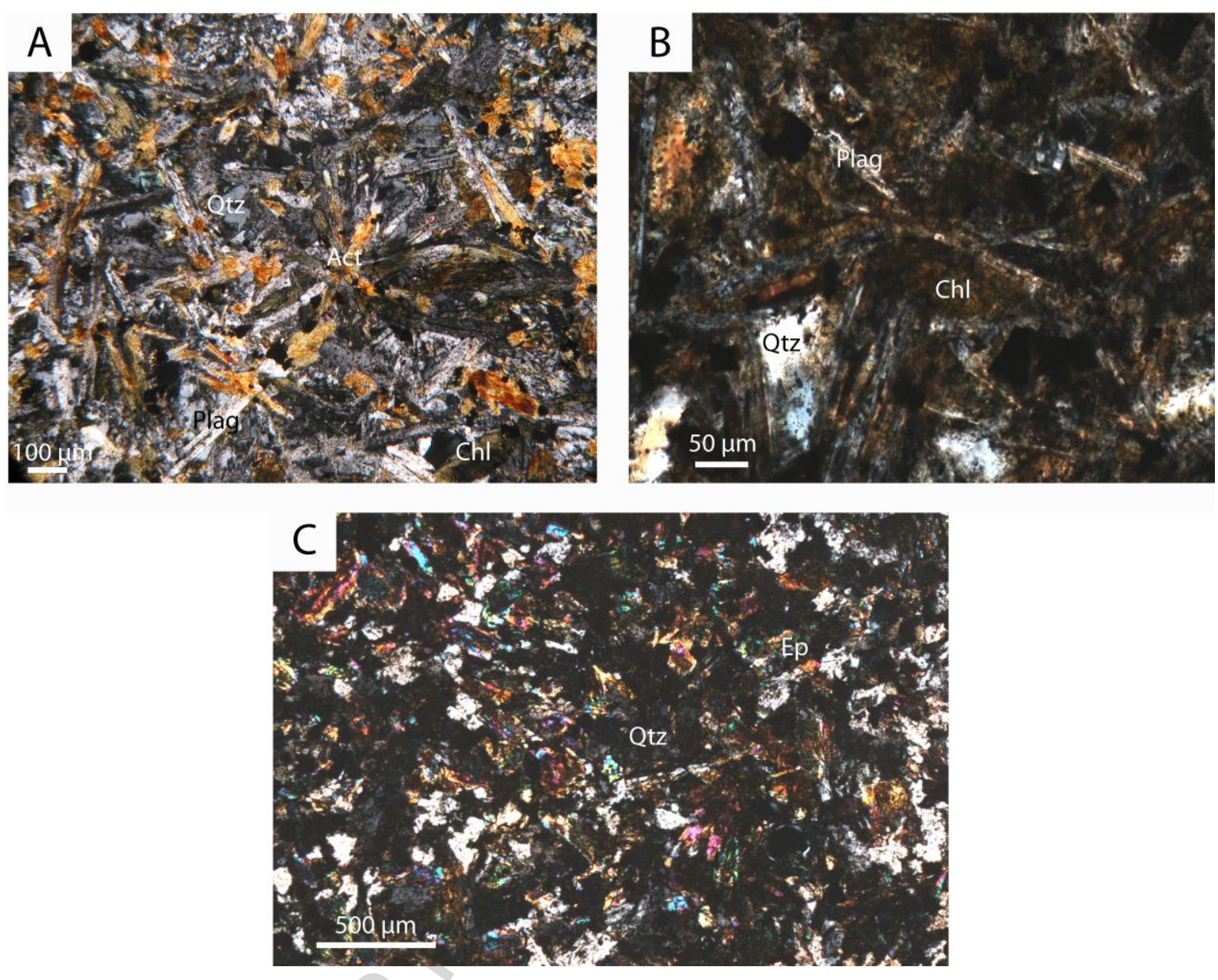

Figure 2 


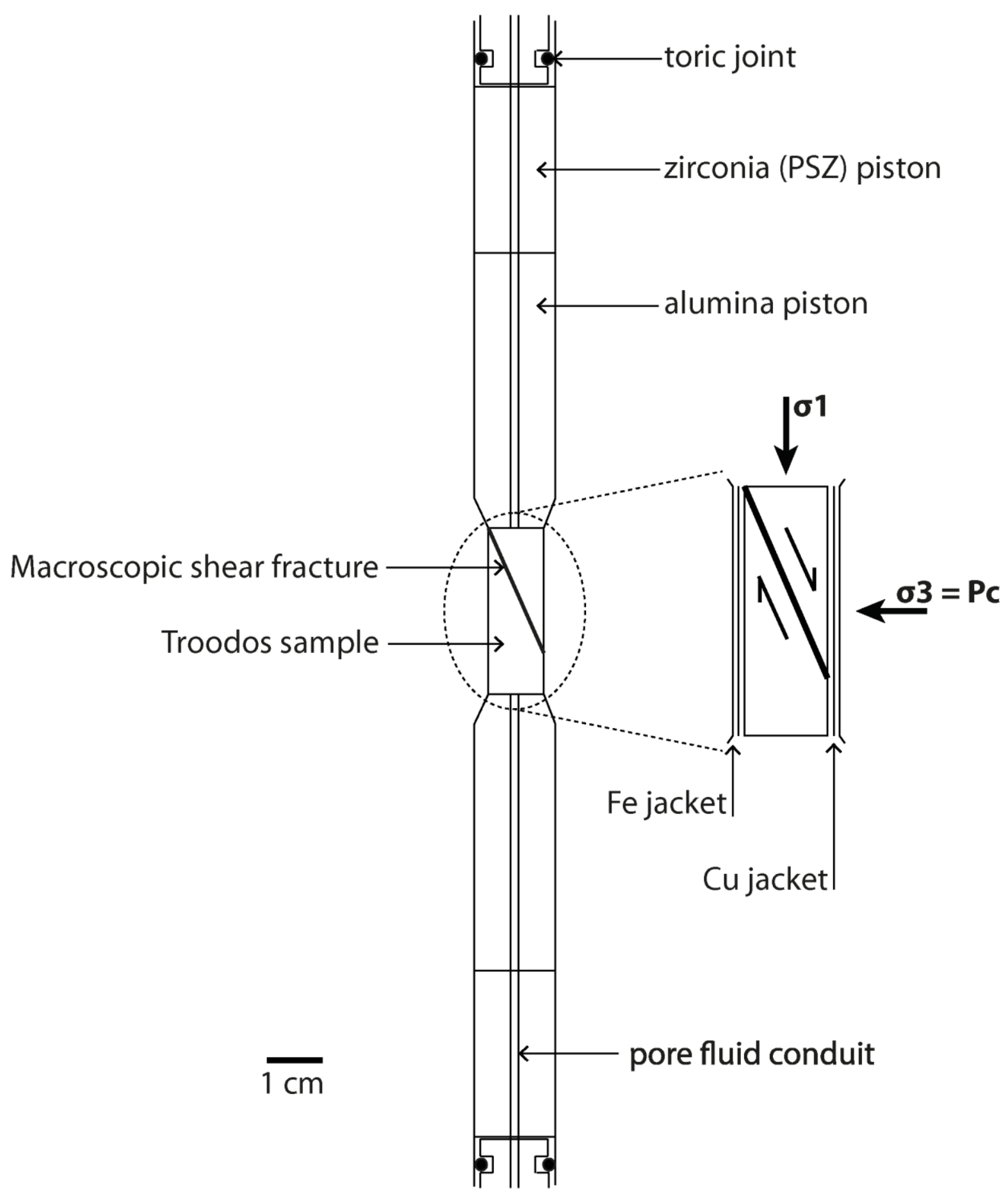

Figure 3 


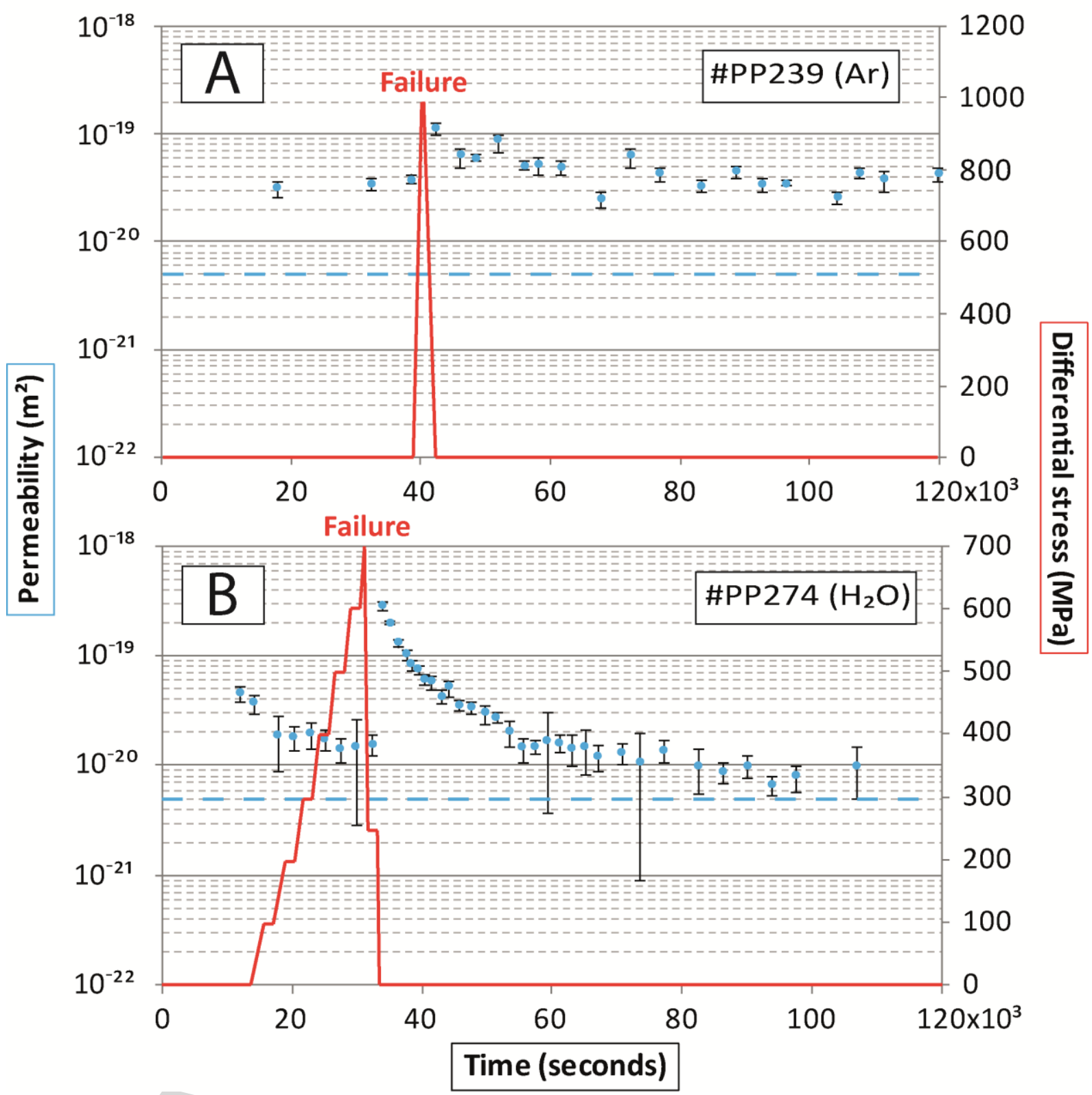

Figure 4 


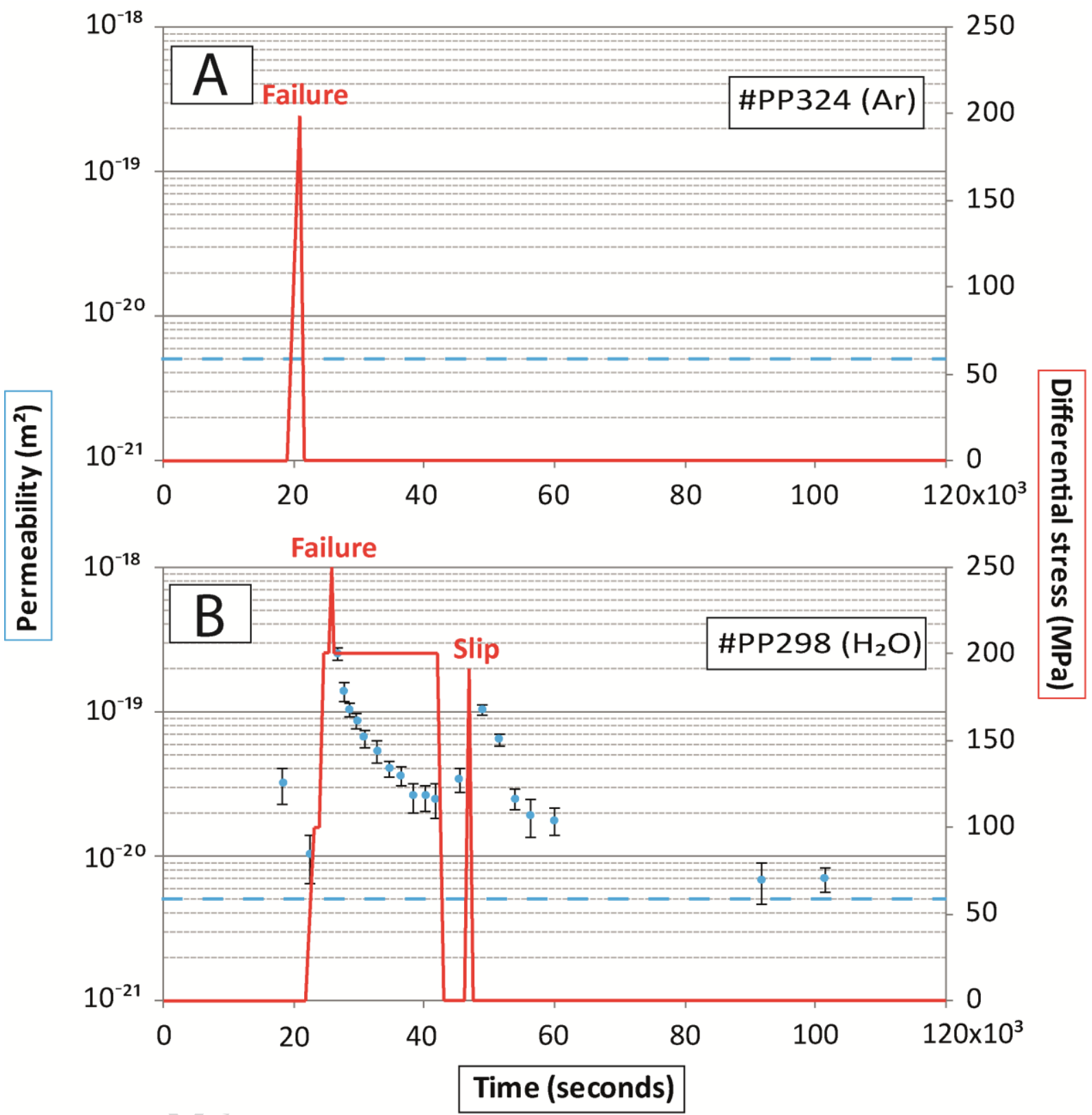

Figure 5 


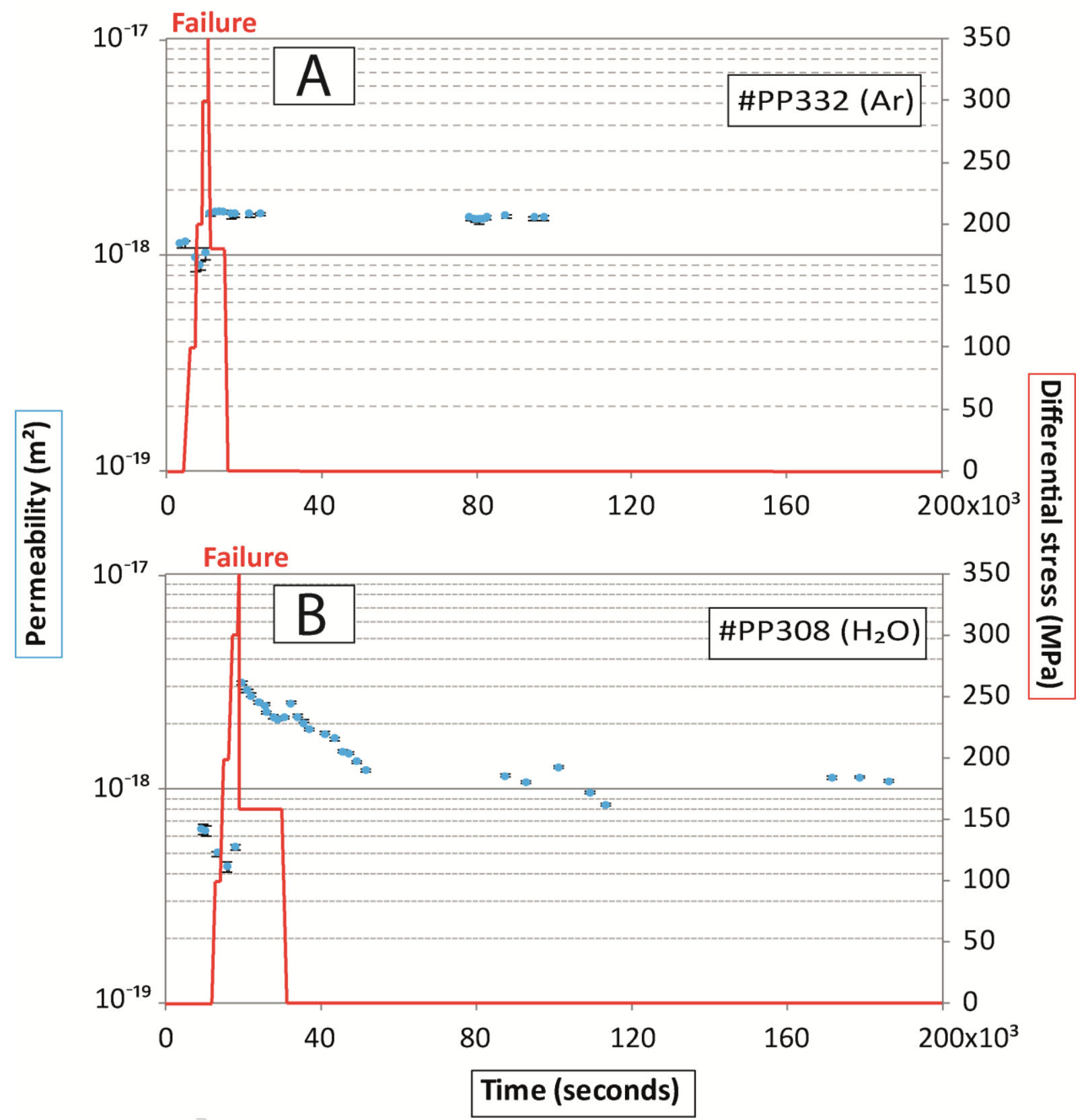

Figure 6 

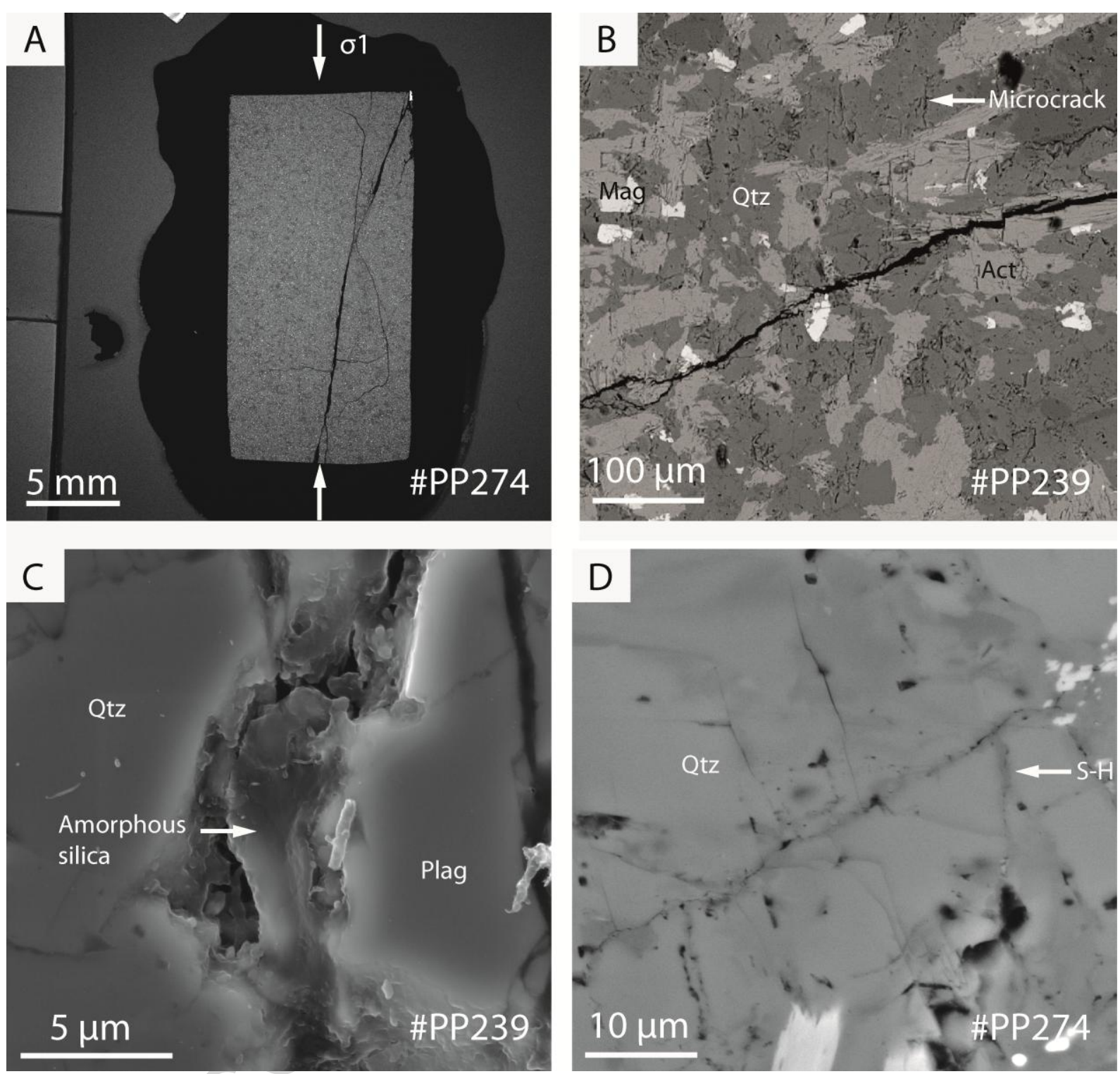

Figure 7 

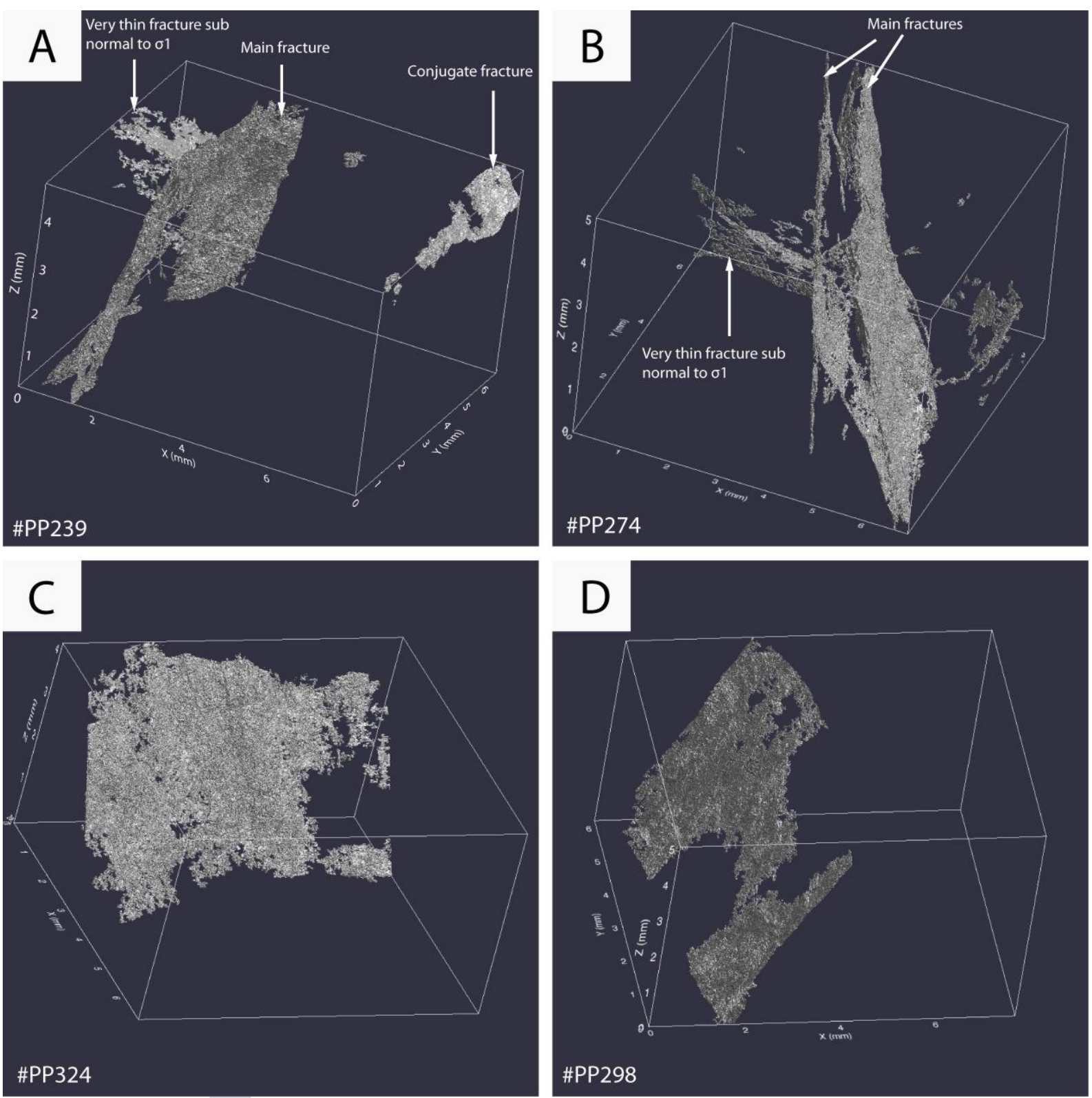

Figure 8 

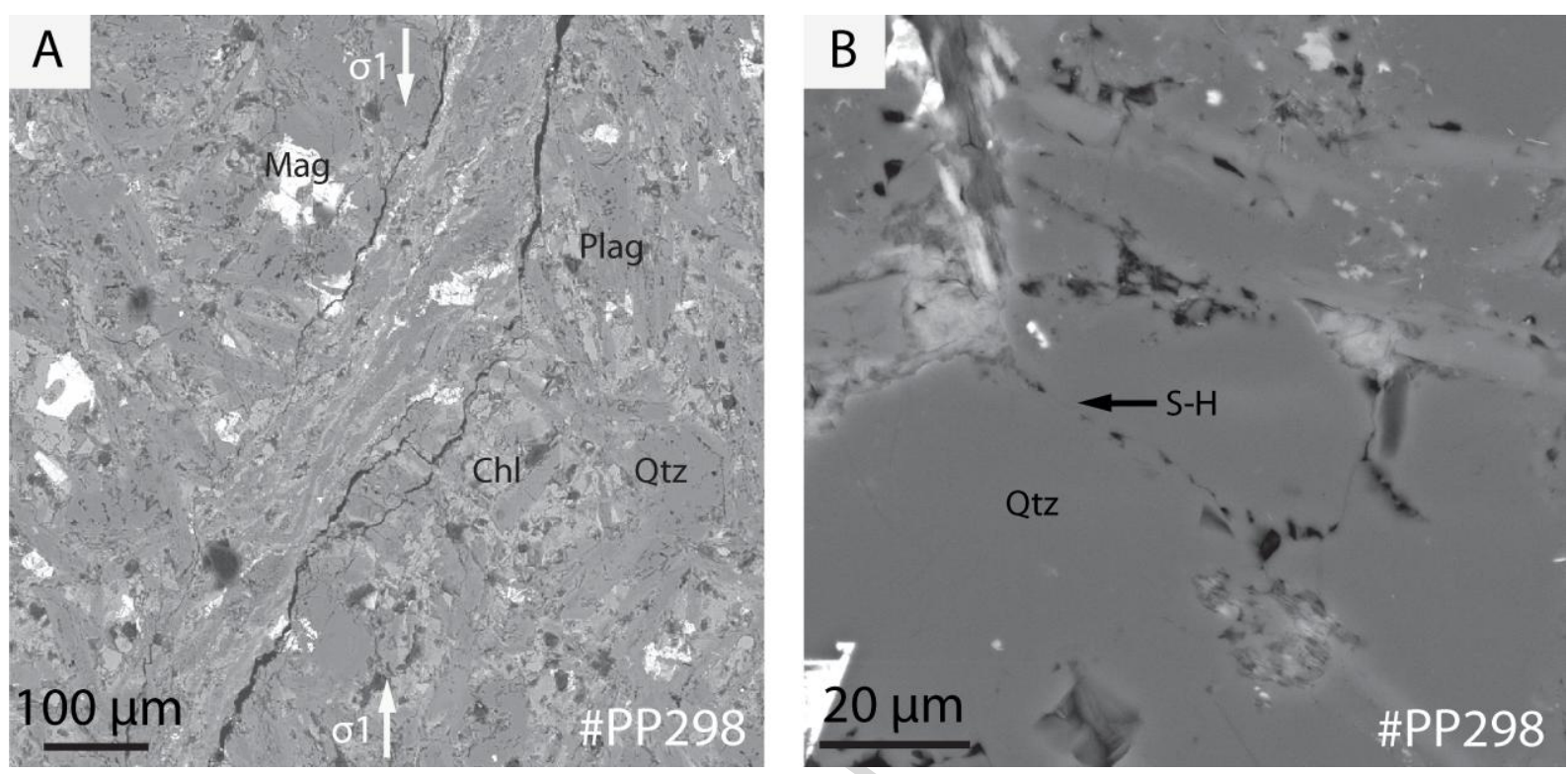

Figure 9 

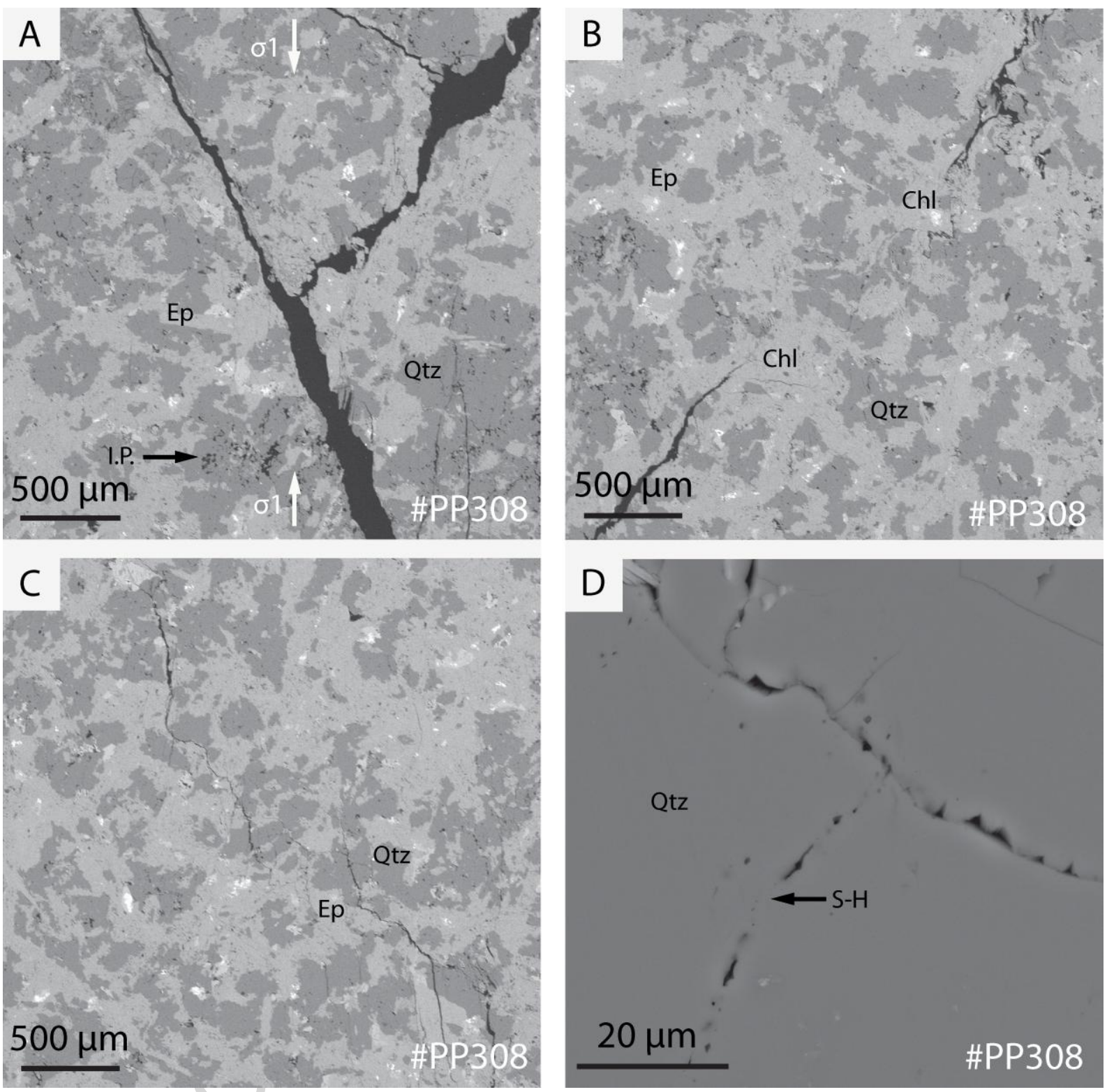

Figure 10 


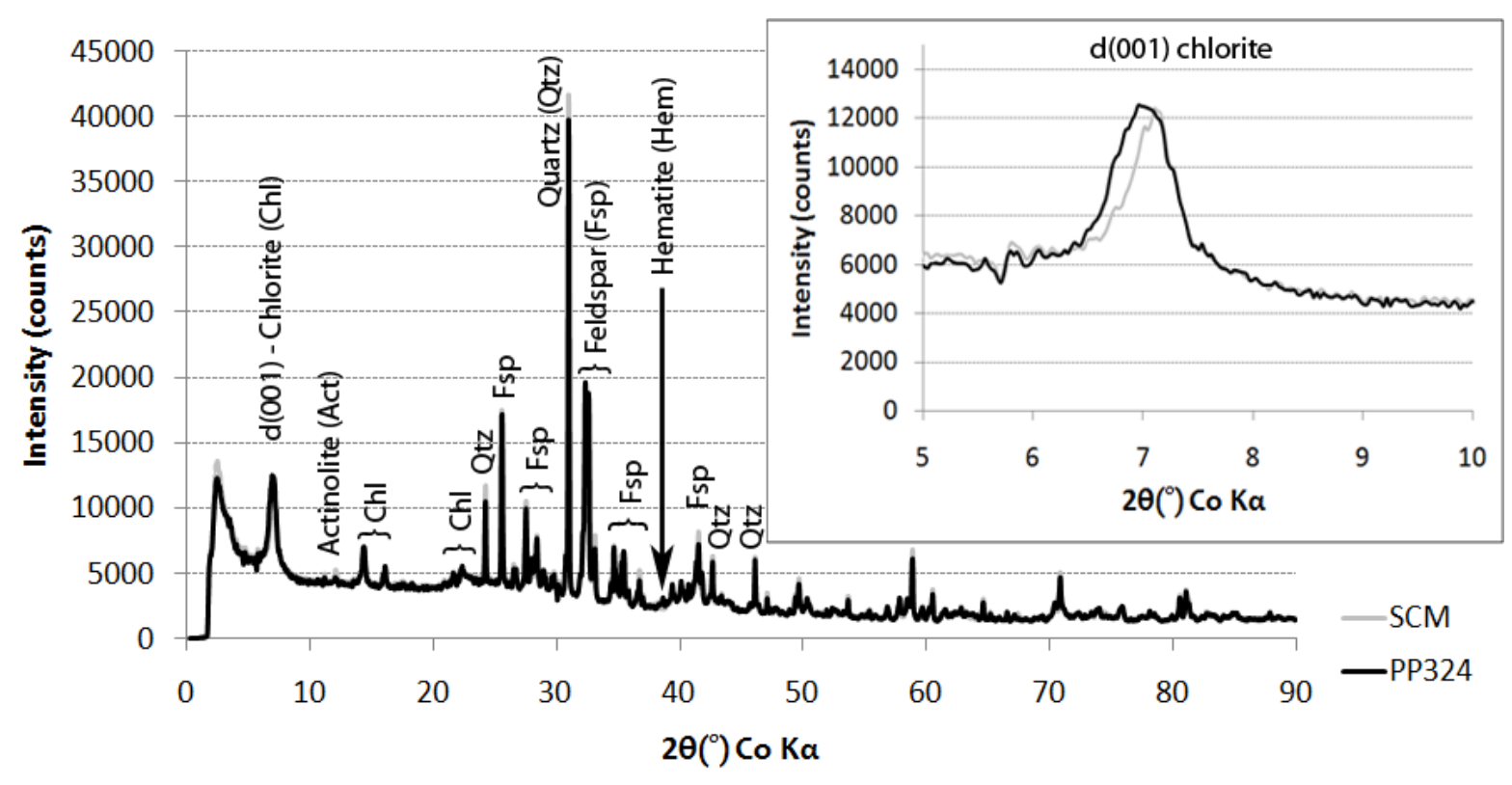

Figure 11 


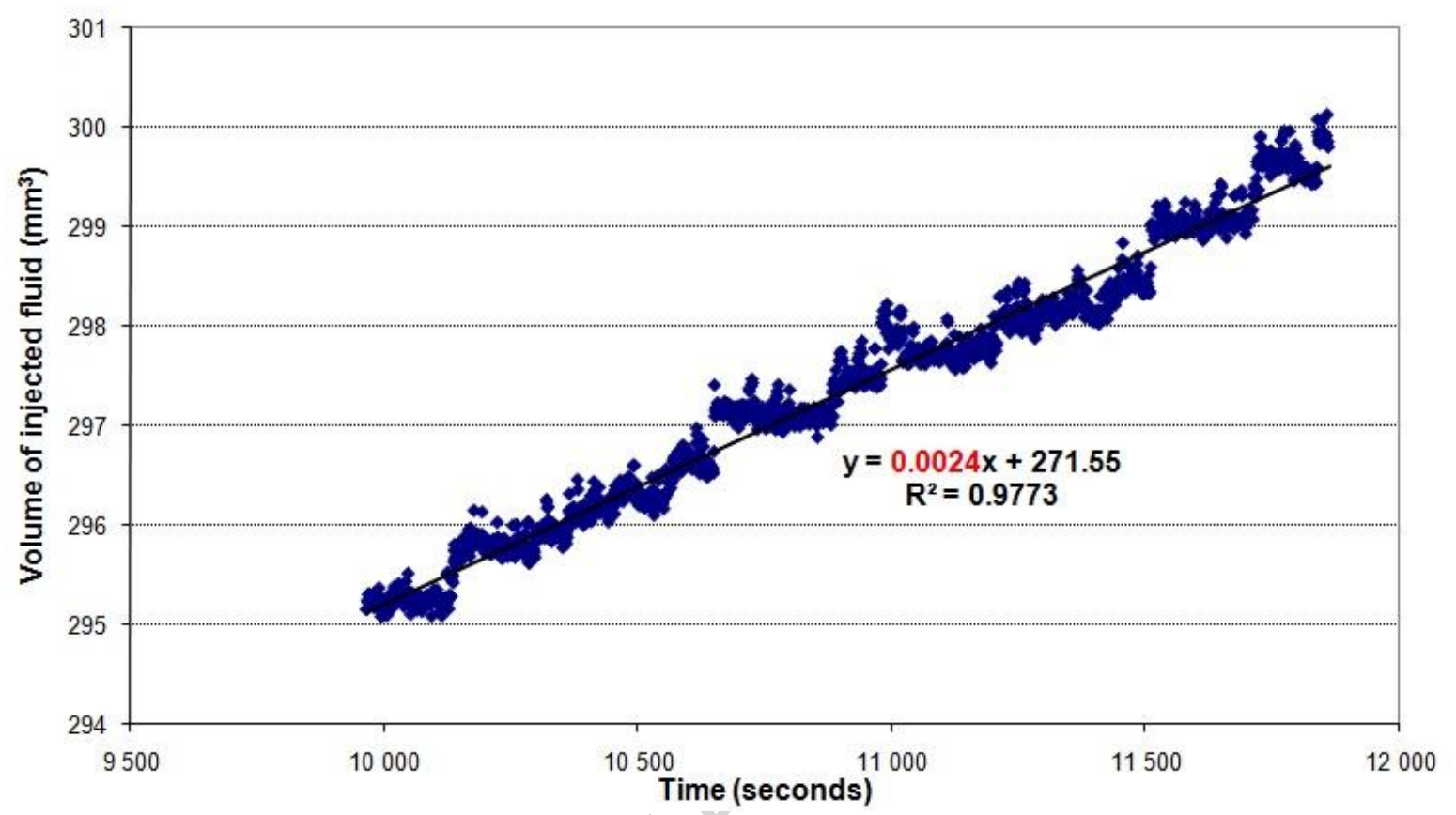

Figure A 


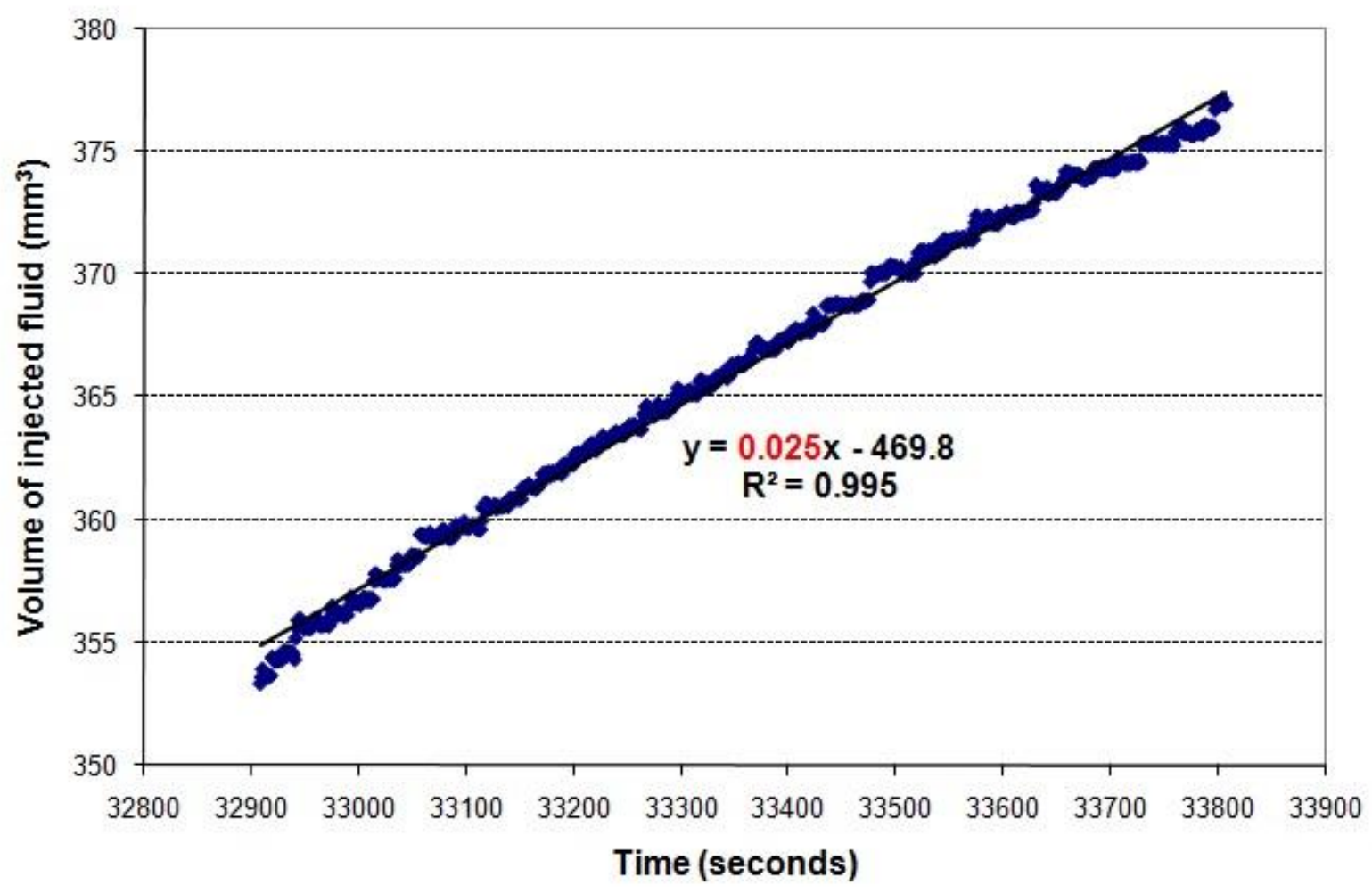

Figure B 


\section{Table 1}

Experiment conditions

\begin{tabular}{llllr}
\hline Run & Sample material & Fluid & $\begin{array}{l}\text { Steps of differential stress (MPa) until } \\
\text { macroscopic failure }\end{array}$ & Duration \\
\hline PP239 & Mtb & Argon gas & $0 \rightarrow 1000$ & 42 hours \\
PP274 & Mtb & De-ionized water & $0-100-200-300-400-500-600 \rightarrow 700$ & 30 hours \\
PP324 & Strongly chloritized mtb & Argon gas & $0 \rightarrow 200$ & 28 hours \\
PP298 & Strongly chloritized mtb & De-ionized water & $0-100-200 \rightarrow 250$ & 28 hours \\
PP332 & Epidosite & Argon gas & $0-100-200-300 \rightarrow 350$ & 27 hours \\
PP308 & Epidosite & De-ionized water & $0-100-200-300 \rightarrow 350$ & 52 hours \\
\hline
\end{tabular}

All of experiments were performed at $\mathrm{Pc}=100 \mathrm{MPa} ; \mathrm{Pp}=50 \mathrm{MPa} ; \mathrm{T}=400^{\circ} \mathrm{C}$; Abbreviation: $\mathrm{Mtb}=$ Metadiabase. 


\section{Highlights}

- We studied relations between permeability, deformation and three alteration facies.

- Permeability reduction after failure is due to self-healing and crack sealing.

- Experiments using argon as pore fluid are not inert because of dehydration.

- Abundance of chlorite generates gouge faults.

- Numerical simulations show permeability overestimation in unloaded samples. 